\title{
Comparative Zone Electrophoresis of Enzymes in the Genus Bacillus
}

\author{
JAMES N. BAPTIST, ${ }^{1}$ MANLEY MANDEL, ${ }^{1}$ AND ROBERT L. GHERNA ${ }^{2}$ \\ Department of Biology, The University of Texas System Cancer Center, M. D. Anderson Hospital and \\ Tumor Institute, Houston, Texas $77030,{ }^{1}$ and American Type Culture Collection, Rockville, Maryland $20852^{2}$
}

\begin{abstract}
Extracts from 88 strains representing a wide variety of Bacillus species were examined by zone electrophoresis, followed by specific stains for each of 11 enzyme activities, and were also analyzed for deoxyribonucleic acid (DNA) buoyant density. Strains representing $B$. megaterium, $B$. cereus, $B$. laterosporus, $B$. firmus, $B$. alvei, $B$. polymyxa, and $B$. macerans exhibited unique patterns of enzyme migrations for each species. Most strains of $B$. subtilis and B. amyloliquefaciens also displayed characteristic enzyme migration patterns for each species. However, one strain, $B$. subtilis KA63, resembled $B$. amyloliquefaciens in DNA composition and enzyme types. It was previously reported to resemble B. amyloliquefaciens in DNA-DNA homology. Another group of strains, which was homogeneous and distinctive in electrophoretic enzyme types, included two strains of $B$. subtilis subsp. niger and one of $B$. subtilis subsp. globigii. Yet another group contained the type strains for $B$. licheniformis, $B$. pulvifaciens, and $B$. coagulans. A second $B$. coagulans strain was quite different from that in the above-mentioned group or from any other Bacillus strain examined. Strains of $B$. pumilus fell into two distinct biotypes according to the electrophoretic data; culturally, they comprised a homogeneous set. Representatives of $B$. thuringiensis, B. bombycis, and $B$. entomocidus were not distinguishable from $B$. cereus by these data.
\end{abstract}

Genetic variability is to be expected within any population. Intuitively, the degree of variability (whether hidden or expressed) is expected to be a function of population size, mutational frequencies, and selection pressure upon the population. This unknown degree of variability affects the manner in which one assembles independently derived (isolated) strains of organisms into nomenclatural groupings. We have continued our attempts to define the range of variability found in functionally active proteins in groups of bacteria by an examination of members of the genus Bacillus. This genus was selected because of the distinctiveness afforded by the complex characters of gram-positive cell walls and endospore formation which are common to all. Representatives of the genus have been extensively and intensively studied by "classical" bacteriological methods $(11,14,16$, $17,20,21,29,31,32,48,55)$ and by the cataloging of ribosomal ribonucleic acid sequences (18). Direct genetic compatibilities have been compared over a more limited range of nomenspecies $(34,38,44)$ in which the recombinations of specific genetic determinants can be assayed. Quasigenetic comparisons of nucleotide sequence homologies have also been performed (44). The genetic and quasi-genetic comparisons have centered on the species $B$. subtilis and phenotypically similar aerobic mesophilic species such as
B. amyloliquefaciens, B. licheniformis, and $B$. pumilus. In addition, comparative studies of complex metabolic regulatory controls that have been completed on a limited number of representative type strains (25) suggest a limited number of subgeneric evolutionary groups within the genus.

The zymogram technique is a potent tool for the detection of minor alterations in protein structure. Homologous proteins will electrophorese at different rates with as little as one amino acid difference; yet these electromorphs are not necessarily infinitely variable (28), and Boyer (12) and Bernstein et al. (10) have detected allelic proteins with identical electrophoretic mobilities. We suggest that selective pressures must operate to conserve a more limited number of electromorphs which retain sufficient enzymatic activity for the organism to survive (27). If this were not so, then a comparison of the electrophoretic mobilities of homologous proteins among a large number of independently derived populations of bacteria of the same genospecies should reveal little constancy of these characters within a species. Our previous experiences with these types of data $(6,7,43)$ clearly indicate that such is not the case for species of gram-negative bacteria. Similar comparisons for other groups should ultimately afford us the data by which to approach the question of 
whether or not there is an equivalence of genetic variability that covers the same general range in the evolution of quite distantly related species.

The zymogram technique has been used to estimate the genetic relationship between sutspecies or related species of a very wide spectrum of living organisms $(1,4,26,30,39,41,45$, $50-52$ ). The results, if a sufficient number of enzymes (five or more) are compared, show that two individuals from different species will differ in the electrophoretic mobility of about $50 \%$ or more of these enzymes, whereas two members of the same species will usually differ in $20 \%$ or less $(2,4,41,45,52)$. Thus, the zymogram technique can be used to identify bacterial species and subspecies. In a previous paper, we reported that zymogram data did not distinguish between Escherichia coli and two Shigella species or between three putative Proteus species (6). However, other types of data support a close genetic relationship in each of those cases $(6$, 13). On the other hand, zymogram data showed that one Pseudomonas cepacia strain is different from other strains of the same species (7), and this difference is paralleled in the heterology estimated by deoxyribonucleic acid (DNA)DNA hybridization (5). In a group of seven Bdellovibrio representatives, zone electrophoresis data indicated that two strains each have a unique set of enzyme types (43). The same two strains were also different from the others in genome size and in DNA sequence homologies, and each was accorded species status (43).

Smith et al. (48) established the subspecies $B$. subtilis subsp. niger on the basis of the formation of a black pigment on media containing tyrosine. However, in the intervening years, many strains of the subspecies have lost the ability to synthesize the characteristic black pigment (20), and as a result the subspecies $B$. subtilis subsp. niger was dropped in several recent reviews of Bacillus taxonomy $(19,20)$. Three strains received as strains of $B$. subtilis subsp. niger are included in this study.

Welker and Campbell described $B$. amyloliquefaciens as a species distinct from $B$. subtilis in 1967 (53). However, their conclusions have been challenged on the ground that the tests recommended to distinguish $B$. amyloliquefa. ciens from $B$. subtilis are not reliable (20). More recently, Seki et al. (44) showed that a group of " $B$. subtilis" strains and several strains of $B$. amyloliquefaciens are similar and quite distinct from the other B. subtilis strains in DNA overall sequence homology and also in specific gene transformation experiments. Therefore, some of the strains, including KA63, that are normal $B$. subtilis strains according to the older classifica- tion methods were assigned to the $B$. amyloliquefaciens group on the basis of these DNADNA homology data and the transformation experiments (44).

$B$. pumilus is very similar to $B$. subtilis, and some authors have suggested reducing it to the status of a subspecies of that species (20). However, the two differ in several properties. $B$. subtilis strains usually hydrolyze starch and reduce nitrate, whereas $B$. pumilus strains do not. On the other hand, $B$. pumilus strains are able to slowly hydrolyze hippurate, whereas $B$. subtilis strains do not. DNA from B. pumilus strains appear to be slightly lower in guanine-plus-cytosine $(\mathrm{G}+\mathrm{C})$ content than that from $B$. subtilis (34). In addition, DNA hybridization studies show that a clear genetic difference separates $B$. pumilus from $B$. subtilis, $B$. licheniformis, or $B$. amyloliquefaciens $(34,44)$. On the other hand, several types of evidence indicate that $B$. pumi$l u s$ and $B$. subtilis are related species. They are similar in appearance and in biochemical capabilities. Genetic transductions in one $B$. pumilus strain have established four linkage groups of amino acid auxotrophs $(35,36)$, and these are similar to linkage groups in $B$. subtilis which involve the same amino acids (33). Certain bacteriophages may be propagated on either $B$. subtilis or on B. pumilus (23). Finally, the DNA homology is a little higher between $B$. pumilus and $B$. subtilis than it is between $B$. pumilus and $B$. megaterium or $E$. coli $(34,44)$.

\section{MATERIALS AND METHODS}

The strains used and their sources are listed in Table 1.

Methods for growth of the bacteria, DNA extraction and analysis, preparation of soluble enzyme extracts, vertical starch gel electrophoresis, and gel stains for most of the enzymes were described previously $(6,8$, $46,47)$. The stain method for pyrophosphatase (PP; EC 3.6.1.1) was described by Shaw and Prasad (46). Superoxide dismutase (SD; EC 1.15.1.1) produced negative staining bands on many of the basic gels. (This activity was previously called tetrazolium oxidase [9, 56].) Esterase is defined, for our purposes, as any enzyme able to catalyze the hydrolysis of $\alpha$ - or $\beta$ naphthyl acetate (46) regardless of the natural function of the enzyme. Most Bacillus species have one or two strong esterase bands at $\mathrm{pH} 7.3$ to 7.4 , the staining conditions used in this study. The much more complex patterns of esterase bands described by Norris in $B$. thuringiensis (40) were produced by staining at a lower $\mathrm{pH}$, so they are not directly comparable with our data. The stain solution for adenylate kinase (46) (AK; EC 2.7.4.3) occasionally discloses two bands of activity, one of which is at the same position as 6phosphogluconate dehydrogenase (6PGD; EC 1.1.1.43) in the gel. Therefore, data are recorded for AK only if the bands of enzyme activity are known to be in a 
TABLE 1. Sources of Bacillus strains examined, the CsCl buoyant density of the DNA, and the calculated base compositions ${ }^{a}$

\begin{tabular}{|c|c|c|c|c|}
\hline \multirow[b]{2}{*}{ Received as } & \multirow[b]{2}{*}{ Strain designation } & \multirow[b]{2}{*}{ Source $^{b}$} & \multicolumn{2}{|c|}{ DNA } \\
\hline & & & $\underset{\left(\mathrm{g} / \mathrm{cm}^{-3}\right)}{\mathbf{P}_{\mathrm{CrCl}}}$ & $\begin{array}{c}\mathrm{G}+\mathrm{C} \\
(\mathrm{mol} \%)\end{array}$ \\
\hline B. subtilis & $\begin{array}{l}168 \\
\text { H } \\
\text { NCIB } 3610^{c} \\
\text { W23 } \\
\text { "Marburg" } \\
\text { B } 765\end{array}$ & $\begin{array}{l}\text { J. Marmur } \\
\text { K. Bott } \\
\text { R. Jensen } \leftarrow \text { ATCC } 6051 \\
\text { N. Sueoka } \\
\text { J. Marmur } \\
\text { NRRL }\end{array}$ & $\begin{array}{l}1.703 \\
1.703 \\
1.703 \\
1.703 \\
1.703 \\
1.701\end{array}$ & $\begin{array}{l}43.8 \\
43.8 \\
43.8 \\
43.8 \\
43.8 \\
41.8\end{array}$ \\
\hline $\begin{array}{l}\text { B. subtilis subsp. niger } \\
B . \text { subtilis subsp. aterri- } \\
\text { mus }\end{array}$ & $\begin{array}{l}\text { OUT } 8111 \\
\text { NRS } 259\end{array}$ & $\begin{array}{l}\text { Y. Oshima } \\
\text { R. Jensen } \leftarrow \text { ATCC } 6460\end{array}$ & $\begin{array}{l}1.704 \\
1.704\end{array}$ & $\begin{array}{l}44.9 \\
44.9\end{array}$ \\
\hline $\begin{array}{l}\text { B. subtilis subsp. globigii } \\
\text { B. subtilis subsp. niger } \\
\text { B. subtilis } \text { subsp. niger }\end{array}$ & $\begin{array}{l}\text { ATCC } 6455 \\
\text { NRS } 1221 \mathrm{~A}\end{array}$ & $\begin{array}{l}\text { R. Jensen } \\
\text { ATCC } \\
\text { NRRL }\end{array}$ & $\begin{array}{l}1.702 \\
1.703 \\
1.702\end{array}$ & $\begin{array}{l}42.9 \\
43.8 \\
42.8\end{array}$ \\
\hline B. pulvifaciens & $\begin{array}{l}\text { NRRL B } 3670^{c} \\
\text { B } 3688\end{array}$ & $\begin{array}{l}\text { R. Jensen } \leftarrow \text { ATCC } 13537 \\
\text { NRRL }\end{array}$ & $\begin{array}{l}1.705 \\
1.706\end{array}$ & $\begin{array}{l}45.9 \\
46.9\end{array}$ \\
\hline B. licheniformis & $\begin{array}{l}9445 \mathrm{~A} \\
\text { NRS } 1264^{c}\end{array}$ & $\begin{array}{l}\text { C. B. Thorne } \\
\text { NRRL }\end{array}$ & $\begin{array}{l}1.704 \\
1.705\end{array}$ & $\begin{array}{l}44.9 \\
45.9\end{array}$ \\
\hline B. pumilus & $\begin{array}{l}\text { AMNH } 794 \\
\text { AMNH } 740 \\
\text { AMNH 501 } \\
\text { AMNH 734a } \\
\text { AMNH 734 } \\
\text { AMNH } 793 \\
\text { NRS 738 } \\
\text { NRS } 725 \\
\text { NRS } 739 \\
\text { NRS 316 } \\
\text { AMNH 726 } \\
\text { NRS 247 } \\
\text { NRS 272 } \\
\text { NRS 355 } \\
\text { NCTC 8241 } \\
\text { M-24-1 } \\
\text { BD 2002 } \\
\text { Bpk 24 } \\
\text { NRRL-B3275 } \\
\text { NCIB-8738 } \\
\text { 101 (NRS 236) }\end{array}$ & $\begin{array}{l}\text { H. Koffler } \leftarrow \text { ATCC } 1 \\
\text { H. Koffler } \leftarrow \text { ATCC } 18 \\
\text { H. Koffler } \leftarrow \text { ATCC } 70 \\
\text { H. Koffler } \leftarrow \text { ATCC } 71 \\
\text { H. Koffler } \leftarrow \text { ATCC } 72 \\
\text { H. Koffler } \leftarrow \text { ATCC } 98 \\
\text { H. Koffler } \leftarrow \text { ATCC } 945 \\
\text { H. Koffler } \leftarrow \text { ATCC } 4510 \\
\text { H. Koffler } \leftarrow \text { ATCC } 4520 \\
\text { H. Koffler } \leftarrow \text { ATCC } 4522 \\
\text { H. Koffler } \leftarrow \text { ATCC } 6631 \\
\text { H. Koffler } \leftarrow \text { ATCC } 6632 \\
\text { H. Koffler } \leftarrow \text { ATCC } 7061 \\
\text { H. Koffler } \leftarrow \text { ATCC } 7065 \\
\text { H. Koffler } \leftarrow \text { ATCC } 14884 \\
\text { H. Koffler } \leftarrow \text { ATCC } 15477 \\
\text { H. Koffler } \\
\text { H. Koffler } \\
\text { H. Koffler } \\
\text { H. Koffler } \\
\text { H. Koffler }\end{array}$ & $\begin{array}{l}1.7015 \\
1.701 \\
1.7015 \\
1.7015 \\
1.701 \\
1.702 \\
1.701 \\
1.702 \\
1.7025 \\
1.7015 \\
1.7015 \\
1.702 \\
1.7015 \\
1.7015 \\
1.7015 \\
1.706 \\
1.702 \\
1.701 \\
1.7015 \\
1.701 \\
1.701\end{array}$ & $\begin{array}{l}42.3 \\
41.8 \\
42.3 \\
42.3 \\
41.8 \\
42.9 \\
41.8 \\
42.9 \\
43.4 \\
42.3 \\
42.3 \\
42.9 \\
42.3 \\
42.3 \\
42.3 \\
46.9 \\
42.9 \\
41.8 \\
42.3 \\
41.8 \\
41.8\end{array}$ \\
\hline B. coagulans & $\begin{array}{l}\text { IFO } 3557 \\
\text { NRS }^{2} 609^{c}\end{array}$ & $\begin{array}{l}\text { Y. Oshima } \\
\text { R. Jensen } \leftarrow \text { ATCC } 7050\end{array}$ & $\begin{array}{l}1.7045 \\
1.706\end{array}$ & $\begin{array}{l}45.4 \\
46.9\end{array}$ \\
\hline B. brevis & & R. Jensen & 1.7043 & 45.2 \\
\hline B. amyloliquefaciens & $\begin{array}{l}\text { Nagase } \\
\text { Fukumoto }^{c} \\
\text { Takamine } 2 \\
146-10 \\
\text { H (Ikeda) } \\
\text { H (wild type) }\end{array}$ & $\begin{array}{l}\text { L. L. Campbell } \\
\text { L. L. Campbell } \\
\text { L. L. Campbell } \\
\text { E. Ho } \\
\text { L. L. Campbell } \\
\text { L. L. Campbell }\end{array}$ & $\begin{array}{l}1.705 \\
1.705 \\
1.705 \\
1.705 \\
1.705 \\
1.705\end{array}$ & $\begin{array}{l}45.9 \\
45.9 \\
45.9 \\
45.9 \\
45.9 \\
45.9\end{array}$ \\
\hline $\begin{array}{l}\text { B. amylosolvens } \\
\text { B. subtilis }\end{array}$ & $\begin{array}{l}\text { OUT } 8341 \\
\text { KA63 }\end{array}$ & $\begin{array}{l}\text { Y. Oshima } \\
\text { Y. Oshima }\end{array}$ & $\begin{array}{l}1.706 \\
1.706\end{array}$ & $\begin{array}{l}46.9 \\
46.9\end{array}$ \\
\hline B. laterosporus & $\begin{array}{l}\text { AMC } 797^{\circ} \\
\text { NRS } 882 \\
\text { B } 344 \\
\text { B } 569\end{array}$ & $\begin{array}{l}\text { R. Jensen } \leftarrow \text { ATCC } 64 \\
\text { NRRL } \\
\text { NRRL } \\
\text { NRRL }\end{array}$ & $\begin{array}{l}1.701 \\
1701 \\
1.697 \\
1.694\end{array}$ & $\begin{array}{l}41.8 \\
41.8 \\
37.8 \\
34.7\end{array}$ \\
\hline B. cereus subsp. mycoides & $\begin{array}{l}\text { B } 346 \\
\text { B } 3711^{c}\end{array}$ & $\begin{array}{l}\text { NRRL } \leftarrow \text { NRS } 233 \\
\text { NRRL }\end{array}$ & $\begin{array}{l}1.6945 \\
1.696\end{array}$ & $\begin{array}{l}35.2 \\
36.7\end{array}$ \\
\hline
\end{tabular}




\begin{tabular}{|c|c|c|c|c|}
\hline \multirow[b]{2}{*}{ Received as } & \multirow[b]{2}{*}{ Strain designation } & \multirow[b]{2}{*}{ Source $^{b}$} & \multicolumn{2}{|c|}{ DNA } \\
\hline & & & $\begin{array}{c}\mathrm{P}_{\mathrm{CsCl}} \\
\left(\mathrm{g} / \mathrm{cm}^{-3}\right)\end{array}$ & $\begin{array}{c}\mathrm{G}+\mathrm{C} \\
(\mathrm{mol} \%)\end{array}$ \\
\hline B. cereus subsp. mycoides & NRS $2 / 3$ & NRRL & 1.696 & 36.7 \\
\hline B. bombycis & $\begin{array}{l}\text { B } 2273 \\
\text { B } 2274\end{array}$ & $\begin{array}{l}\text { NRRL } \\
\text { NRRL }\end{array}$ & $\begin{array}{l}1.6945 \\
1.695\end{array}$ & $\begin{array}{l}35.2 \\
35.7\end{array}$ \\
\hline B. thuringiensis & B 2172 & $\begin{array}{l}\text { NRRL } \\
\text { R. Jensen }\end{array}$ & $\begin{array}{l}1.695 \\
1.696\end{array}$ & $\begin{array}{l}35.7 \\
36.7\end{array}$ \\
\hline B. entomocidus & $\begin{array}{l}\text { NRS } 1124 \\
\text { NRS } 1328\end{array}$ & $\begin{array}{l}\text { NRRL } \\
\text { NRRL }\end{array}$ & $\begin{array}{l}1.696 \\
1.695\end{array}$ & $\begin{array}{l}36.7 \\
35.7\end{array}$ \\
\hline $\begin{array}{l}\text { B. circulans } \\
\text { B. pantothenticus } \\
\text { B. finitimus }\end{array}$ & $\begin{array}{l}\text { NRS } 1321^{c} \\
\text { NRRL-B2245 }\end{array}$ & $\begin{array}{l}\text { R. Jensen } \\
\text { R. Jensen } \leftarrow \text { ATCC } 14576 \\
\text { R. Jensen }\end{array}$ & $\begin{array}{l}1.696 \\
1.696 \\
1.6963\end{array}$ & $\begin{array}{l}36.7 \\
36.7 \\
37.0\end{array}$ \\
\hline B. megaterium & $\begin{array}{l}\text { B } 1827 \\
\text { P. B. Cowles C9 (M1) } \\
\text { NRS } 895 \\
\text { B } 349 \\
\text { B } 3712^{c}\end{array}$ & $\begin{array}{l}\text { NRRL } \\
\text { NRRL } \leftarrow \text { ATCC } 1561 \\
\text { NRRL } \\
\text { NRRL } \\
\text { NRRL }\end{array}$ & $\begin{array}{l}1.6985 \\
1.6995 \\
1.698 \\
1.698 \\
1.699\end{array}$ & $\begin{array}{l}39.3 \\
40.3 \\
38.8 \\
38.8 \\
39.8\end{array}$ \\
\hline $\begin{array}{l}\text { Myxogeotrichium filar- } \\
\text { ioides }\end{array}$ & & A. Castellani & 1.6985 & 39.3 \\
\hline B. firmus & NRS 613 & $\begin{array}{l}\text { R. Jensen } \\
\text { NRRL }\end{array}$ & $\begin{array}{l}1.701 \\
1.7015\end{array}$ & $\begin{array}{l}41.8 \\
42.3\end{array}$ \\
\hline $\begin{array}{l}\text { B. sphaericus } \\
\text { B. pyschrophilus }\end{array}$ & $\begin{array}{l}\text { NCIB } 9370^{c} \\
\text { W16A }^{c}\end{array}$ & $\begin{array}{l}\text { R. Jensen } \leftarrow \text { ATCC } 14577 \\
\text { R. Jensen }\end{array}$ & $\begin{array}{l}1.6975 \\
\mathrm{ND}^{d}\end{array}$ & $\begin{array}{l}38.3 \\
\text { ND }\end{array}$ \\
\hline B. alvei & $\begin{array}{l}\text { B } 385 \\
\text { B } 383 \\
\text { NRS } 685 \\
\text { NRS } 662^{c}\end{array}$ & $\begin{array}{l}\text { NRRL } \\
\text { NRRL } \leftarrow \text { NRS } 662 \\
\text { R. Jensen } \leftarrow \text { ATCC } 10871 \\
\text { R. Jensen } \leftarrow \text { ATCC } 6344\end{array}$ & $\begin{array}{l}1.705 \\
1.7055 \\
1.7065 \\
1.7065\end{array}$ & $\begin{array}{l}45.9 \\
46.4 \\
47.4 \\
47.4\end{array}$ \\
\hline B. macerans & $\begin{array}{l}\text { B } 172 \\
\text { B } 171 \\
\text { B } 388 \\
\text { B } 70 \\
\text { B 430 } \\
\text { NCA } 7 \text { X1 }\end{array}$ & $\begin{array}{l}\text { NRRL } \\
\text { L. E. Sacks, WRRL } \leftarrow \text { NRRL } \\
\text { L. E. Sacks, WRRL } \leftarrow \text { NRRL } \\
\text { L. E. Sacks, WRRL } \leftarrow \text { NRRL } \\
\text { L. E. Sacks, WRRL } \leftarrow \text { NRRL } \\
\text { L. E. Sacks, WRRL }\end{array}$ & $\begin{array}{l}1.7125 \\
1.713 \\
1.713 \\
1.713 \\
1.713 \\
1.713\end{array}$ & $\begin{array}{l}53.6 \\
54.1 \\
54.1 \\
54.1 \\
54.1 \\
54.1\end{array}$ \\
\hline B. polymyxa & $\begin{array}{l}\text { NRS } 1105^{c} \\
\text { BP } 101 \\
\text { BP } 102 \\
\text { BP } 103\end{array}$ & $\begin{array}{l}\text { NRRL } \\
\text { ICPB } \\
\text { ICPB } \\
\text { ICPB }\end{array}$ & $\begin{array}{l}1.705 \\
1.706 \\
1.7065 \\
1.706\end{array}$ & $\begin{array}{l}45.9 \\
46.9 \\
47.4 \\
46.9\end{array}$ \\
\hline B. stearothermophilus & $\mathrm{NCA} 26^{c}$ & O. L. Harris $\leftarrow$ ATCC 12980 & 1.711 & 52.0 \\
\hline
\end{tabular}

${ }^{a}$ Abbreviations employed: AMC, Walter Reed Army Medical Center, Washington, D.C.; AMNH, American Museum of Natural History, New York, N.Y.; ATCC, American Type Culture Collection, Rockville, Md.; ICPB, International Collection of Phytopathogenic Bacteria, University of California, Davis, Calif.; IFO, Institute for Fermentation, Osaka, Japan; NCA, National Canners Association, Washington, D.C.; NCIB, National Collection of Industrial Bacteria, Aberdeen, Scotland; NCTC, National Collection of Type Cultures, London, England; NRS, N. R. Smith; NRRL, Northern Utilization Research and Development Division, U.S. Department of Agriculture, Peoria, Ill.; OUT, Department of Fermentation Technology, Osaka University, Suita, Japan; WRRL, Western Regional Research Laboratory, U.S. Department of Agriculture, Albany, Calif.

${ }^{b}$ Individuals from whom strains were obtained are located as follows: J. Marmur, Albert Einstein College of Medicine, Yeshiva University, Bronx, N.Y.; K. Bott, University of North Carolina School of Medicine, Chapel Hill, N.C.; R. Jensen, State University of New York, Binghamton, N.Y.; Y. Oshima, Osaka University, Suita, Japan; C. B. Thorne, University of Massachusetts, Amherst, Mass.; H. Koffler, University of Minnesota, Minneapolis, Minn.; L. L. Campbell, University of Delaware, Newark, Del.; E. Ho, Miles Laboratories, Elkhart, Ind.; A. Castellani is deceased; the strain obtained from him has also been deposited with ATCC and NRRL; O. L. Harris, University of Missouri, Columbia, Mo.

${ }^{c}$ Designates type or neotype strain.

${ }^{d}$ ND, Not determined. 
different position than 6PGD bands, as determined on longitudinal sections of the gel stained separately for the latter enzyme.

The tris(hydroxymethyl)aminomethane (Tris)-citrate buffer system (46) was used with an 18-h electrophoresis period for malate dehydrogenase $(\mathrm{MDH}$; EC 1.1.1.37). The same buffer with a 6 -h electrophoresis period was utilized for the enzymes adenylate kinase, triosephosphate isomerase (TPI; EC 5.3.1.1), and PP. The following enzymes were localized on gels made with the Tris-ethylenediaminetetraacetic acid-borate buffer system (46) and an 18-h electrophoresis period: 6PGD, glucose-6-phosphate dehydrogenase (G6PD; EC 1.1.1.49), superoxide dismutase, alanine dehydrogenase (Ala DH; EC 1.4.1.1), and L-leucine dehydrogenase (Leu DH; EC 1.4.1.9). Esterase and catalase (EC 1.11.1.6) were ordinarily studied with a borate buffer system ( $\mathrm{pH} 8.0$ ) and an 18-h electrophoresis period. However, in certain cases, Tris-citrate gels $(\mathrm{pH}$ 7.0) were also used to provide additional information for distinguishing esterase and catalase activities. Assignment of a particular enzyme to an "enzyme type" or "isozyme type" was usually based on at least two experiments in different gels in each case. The only exception was the $B$. pumilus strains of biotype II in which a large number of very similar strains were examined and single runs were performed. Phenotypic properties of the $B$. pumilus strains were determined by the procedures of Gordon et al. (20).

\section{RESULTS}

The DNA buoyant densities in neutral $\mathrm{CsCl}$ for most of the strains are listed in Table 1 .

The primary data recorded for each starch gel were the migration distances for each enzyme band and the identity or nonidentity in position of each adjacent pair of bands. In doubtful cases, bands were considered identical unless they could be consistently distinguished. A standard enzyme source was added to at least one slot of each gel, and the migration distances were divided by the migration distance of this standard to reduce the amount of variation between gels. In most cases, this standard was a rat liver extract, and the corresponding rat liver enzymes were used as standards for 6PGD, G6PD, and $\mathrm{MDH}$. In the case of G6PD, the slowest of three rat liver isozyme bands was used. Rat liver SD bands were the standards for bacterial SD, Ala $\mathrm{DH}$, Leu DH, and TPI. Methyl red was used as a standard for catalase and esterase, the $\mathrm{AK}$ band in $B$. thuringiensis was used for the other bacterial AK types, and the PP band in $B$. subtilis 168 was used for other bacterial PP types.

When the above migration ratios were averaged for all the strains containing a particular isozyme or electromorph and tabulated (Tables 2 through 10 ), we found a few cases in which two distinguishable types were represented by the same number. One example was the isozyme of
6PGD found in most $B$. subtilis strains and in a $B$. pumilus strain. It was easily distinguished on most gels from a similar form in B. amylolique. faciens, $B$. megaterium, and $B$. subtilis subsp. niger strains, but both isozymes produced calculated average migration ratios of 2.5. Figure 1 illustrates these two enzyme types. In Tables 2 through 10, a series of footnotes was used when necessary to indicate distinguishable enzyme molecules which had the same average migration ratios. We assigned the same weight to these small differences as to larger differences in migration distance because either may be due to a single amino acid substitution or to a posttranslational modification.

Table 2 shows the enzyme types for some common Bacillus species, whereas subsequent tables show the variation among strains for many of the same species.

In Table 3 data from seven strains of $B$. subtilis are shown. Six of the strains were relatively similar to each other, with variation confined to four enzyme proteins, Ala $\mathrm{DH}, \mathrm{MDH}, \mathrm{AK}$, and the weaker of two catalase bands. However, the last strain listed, OUT 8111, was quite unusual. It had unique mobilities for 5 enzymes of the 11 available for study. (The two esterase bands were counted as two independent gene products.) We also examined single strains provided as $B$. vulgatus and $B$. pasteurii. Both strains were identical to $B$. subtilis 168 in their enzyme types and DNA base composition. The laboratory which provided these specimens employs $B$. subtilis 168 regularly and we concluded that there was an excellent chance that the histories of these strains were "clouded."

The last three columns of Table 3 are representatives of another distinctive Bacillus type, differing from either $B$. subtilis or B. amyloliquefaciens in 8 or 9 enzymes, respectively, of 11 . All three strains were received as $B$. subtilis subsp. niger or $B$. globigii, but not all of the $B$. subtilis subsp. niger strains fell into this group. Two other strains that were received under other species names and which are not included in the tables also fell into this group. All five strains were homogeneous; no variant enzymes were found. The only variation noticed in these strains was a pink color in the packed cells and enzyme extracts of $B$. globigii.

Another genetic group, only slightly less homogeneous in enzyme types, is shown in Table 4. This group of seven Bacillus strains contained strains received under five different species or subspecies names. In this group were two strains each of $B$. pulvifaciens and $B$. licheniformis and one of $B$. coagulans, including the type strain of each species. However, a second representative 
TABLE 2. Comparative electrophoretic migrations of enzymes in various representatives of the genus Bacillus

\begin{tabular}{|c|c|c|c|c|c|c|c|c|c|c|c|c|c|c|}
\hline Enzyme & 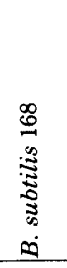 & 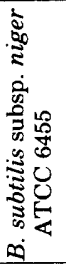 & 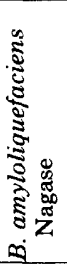 & 蛋 & 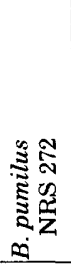 & 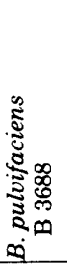 & 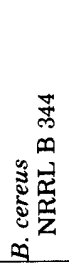 & 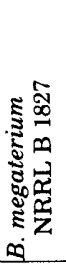 & 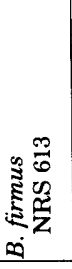 & 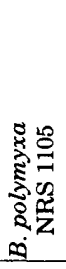 & 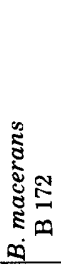 & 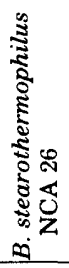 & 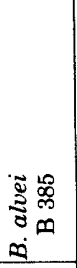 & 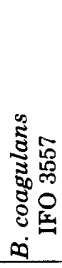 \\
\hline SD . . & 2.2 & 2.1 & 2.2 & 2.2 & 2.2 & 2.0 & 2.2 & 2.5 & 2.5 & 1.70 & 1.32 & 1.79 & 2.3 & 2.1 \\
\hline 6PGD & $2.5^{a}$ & $2.5^{b}$ & $2.5^{b}$ & $2.5^{a}$ & 1.93 & $2.1^{c}$ & & $2.5^{b}$ & $2.1^{d}$ & 1.97 & 1.91 & 1.49 & $2.1^{c}$ & 2.0 \\
\hline G6PD & 3.7 & $3.2^{e}$ & 3.2 & 3.7 & $3.2^{e}$ & 2.9 & 4.2 & 4.2 & 3.4 & 2.7 & 2.4 & 1.94 & 2.9 & 1.9 \\
\hline G6PD . & & & & & & & & & & 5.4 & 3.7 & & 3.7 & \\
\hline Ala DH & 1.16 & 1.20 & 0.90 & 1.20 & 1.17 & 1.07 & 1.20 & 1.11 & 1.11 & & & 0.73 & 1.11 & 0.56 \\
\hline Ala DH. & & & & & & & & & & & & 0.93 & & \\
\hline Leu DH & 0.99 & 0.96 & $0.93^{f}$ & $0.93^{f}$ & $0.93^{f}$ & 1.00 & 1.00 & 1.00 & $0.93^{g}$ & & & 0.67 & & 0.89 \\
\hline Leu DH . & & & & & & & & & & & & 0.73 & & \\
\hline MDH $\ldots \ldots$ & 1.52 & 1.34 & 1.38 & 1.58 & 1.48 & 1.52 & 1.42 & 1.23 & 1.23 & 1.52 & & $\begin{array}{l}0.51 \\
0.86\end{array}$ & 1.75 & 1.06 \\
\hline $\begin{array}{l}\text { MDH ... } \\
\text { Catalase }\end{array}$ & 0.44 & 0.41 & 0.45 & 0.44 & 0.44 & 0.44 & 0.44 & 0.44 & 0.35 & 0.44 & 0.44 & $\begin{array}{l}0.86 \\
0.47\end{array}$ & $0.44^{h}$ & 0.44 \\
\hline Esterase & 0.47 & 0.47 & 0.47 & 0.39 & 0.40 & 0.47 & & 0.83 & & 0.24 & 0.51 & 0.29 & 0.52 & 0.67 \\
\hline Esterase & 0.97 & 0.87 & 0.97 & & & & & & & 0.74 & 0.74 & 0.61 & & \\
\hline Esterase & & & & & & & & & & & 1.02 & & & \\
\hline AK $\ldots$. & 1.14 & 1.14 & 1.10 & 0.99 & 0.84 & 1.10 & 0.99 & & 0.99 & 0.70 & 0.62 & 0.43 & 1.00 & 0.89 \\
\hline TPI & 3.9 & 3.9 & 3.8 & 3.7 & 4.2 & 3.5 & 4.0 & 5.3 & 2.9 & 2.5 & 2.5 & 3.5 & 2.8 & 3.1 \\
\hline $\mathrm{PP}$ & 0.99 & & & 0.88 & 1.09 & & 0.99 & 1.09 & 0.88 & 0.79 & 0.79 & 0.76 & 0.83 & 0.99 \\
\hline
\end{tabular}

${ }^{a}$ The 6PGD types found in B. subtilis 168 and in B. pumilus AMNH 793 were not distinguishable under the conditions used.

${ }^{b}$ The 6 PGD type found in strain ATCC 6455 was not distinguishable from that found in B. amyloliquefaciens or in $B$. megaterium, but it did migrate slightly faster than the enzyme designated $2.5^{a}$.

' The 6PGD type found in B. pulvifaciens matched that in B. alvei but migrated slightly faster than the type found in $B$. firmus.

${ }^{d}$ The 6PGD type in $B$. firmus.

e This isozyme migrated more slowly than the G6PD enzyme of $B$. amyloliquefaciens.

$f$ The Leu DH type found in $B$. pumilus and $B$. amyloliquefaciens differed from and migrated slightly faster than the type found in $B$. firmus.

$g$ The Leu DH isozyme found in $B$. firmus.

${ }^{h}$ The catalase type in $B$. alvei migrated faster than the isozyme found in $B$. subtilis and many other strains, even though the average migration ratios were equal.

TABLE 3. Comparative electrophoretic migrations of enzymes in B. subtilis and B. subtilis subsp. niger

\begin{tabular}{|c|c|c|c|c|c|c|c|c|c|c|}
\hline Enzyme & $\begin{array}{c}\text { B. subtilis } \\
168\end{array}$ & $\begin{array}{c}\text { B. subtilis } \\
\mathrm{H}\end{array}$ & $\begin{array}{l}\text { B. subtilis } \\
\text { NCIB } \\
3610\end{array}$ & $\begin{array}{l}\text { B. subtilis } \\
\text { W23 }\end{array}$ & $\begin{array}{l}\text { B. subtilis } \\
\text { "Mar- } \\
\text { burg" }\end{array}$ & $\begin{array}{l}\text { B. subtilis } \\
\text { B765 }\end{array}$ & $\begin{array}{l}\text { B. subtilis } \\
\text { subsp. ni- } \\
\text { ger OUT } \\
8111\end{array}$ & $\begin{array}{c}\text { B. subtilis } \\
\text { subsp. } \\
\text { globigii }\end{array}$ & $\begin{array}{l}\text { B. subtilis } \\
\text { subsp. ni- } \\
\text { ger ATCC } \\
\quad 6455\end{array}$ & $\begin{array}{l}\text { B. subtilis } \\
\text { subsp. ni- } \\
\text { ger NRS } \\
1221 \mathrm{~A}\end{array}$ \\
\hline $\mathrm{SD}$ & .2 .2 & 2.2 & 2.2 & 2.2 & 2.2 & 2.2 & 1.8 & 2.0 & 2.0 & 2.0 \\
\hline 6PGD & 2.5 & 2.5 & 2.5 & 2.5 & 2.5 & 2.5 & $2.5^{a}$ & $2.5^{b}$ & $2.5^{b}$ & $2.5^{b}$ \\
\hline G6PD . & .3 .7 & 3.7 & 3.7 & 3.7 & 3.7 & 3.7 & 3.7 & $3.2^{c}$ & $3.2^{c}$ & $3.2^{c}$ \\
\hline Ala DH & 1.16 & 1.16 & 1.16 & $1.11^{d}$ & $1.11^{d}$ & 1.16 & 1.27 & $1.20^{e}$ & $1.20^{e}$ & $1.20^{e}$ \\
\hline Leu DH & 0.99 & 0.99 & 0.99 & 0.99 & 0.99 & 0.99 & 0.99 & 0.96 & 0.96 & 0.96 \\
\hline MDH . . & 1.52 & 1.52 & 1.52 & $1.42^{f}$ & $1.42^{\prime}$ & $1.42^{f}$ & $1.42^{f}$ & 1.34 & 1.34 & 1.34 \\
\hline Catalase & 0.44 & 0.44 & 0.44 & 0.44 & 0.44 & 0.44 & 0.44 & 0.41 & 0.41 & \\
\hline Catalase & .0 .28 & 0.28 & & 0.36 & 0.36 & 0.28 & & & & \\
\hline Esterase & .0 .47 & 0.47 & 0.47 & 0.47 & 0.47 & 0.47 & 0.47 & 0.47 & 0.47 & 0.47 \\
\hline Esterase & .0 .97 & 0.97 & 0.97 & 0.97 & 0.80 & 0.95 & 1.04 & 0.87 & 0.87 & 0.87 \\
\hline AK .... & .1 .14 & 1.14 & 1.14 & 1.14 & 1.14 & 1.14 & 1.18 & 1.14 & 1.14 & 1.14 \\
\hline TPI & 3.9 & 3.9 & 3.8 & 3.8 & 3.8 & 3.9 & 3.9 & 3.9 & 3.9 & 3.9 \\
\hline PP . & 0.99 & & & 0.99 & 0.99 & 0.99 & & & & \\
\hline
\end{tabular}

\footnotetext{
${ }^{a}$ The 6PGD isozyme in this strain migrated slightly slower than the isozyme found in $B$. subtilis 168 .

${ }^{b}$ This appeared to match the 6PGD band in $B$. amyloliquefaciens and $B$. megaterium but not in $B$. subtilis 168.

'This migrated more slowly than the G6PD band in B. amyloliquefaciens.

${ }^{d}$ The Ala DH band in certain $B$. subtilis strains appeared identical to that in $B$. megaterium and $B$. firmus.

e This matched the Ala DH band in $B$. cereus.

${ }^{f}$ The MDH type in four $B$. subtilis strains appeared identical to that in $B$. cereus.
} 
TABLE 4. Comparative electrophoretic migrations of enzymes in B. licheniformis-like strains

\begin{tabular}{|c|c|c|c|c|c|c|c|c|}
\hline Enzyme & $\begin{array}{c}\text { B. subtilis } \\
168\end{array}$ & $\begin{array}{l}\text { B. pulvifa- } \\
\text { ciens } \\
\text { B } 3670\end{array}$ & $\begin{array}{c}\text { B. pulvifa- } \\
\text { ciens } \\
\text { B } 3688\end{array}$ & $\begin{array}{l}\text { B. licheni- } \\
\text { formis } \\
9445 \mathrm{~A}\end{array}$ & $\begin{array}{l}\text { B. licheni. } \\
\text { formis } \\
\text { NRS } 1264\end{array}$ & $\begin{array}{l}\text { B. coagu- } \\
\text { lans } \\
\text { NRS } 609\end{array}$ & B. brevis & $\begin{array}{l}\text { B. subtilis } \\
\text { subsp. } \\
\text { aterrimus } \\
\text { NRS } 259\end{array}$ \\
\hline SD & 2.2 & 2.0 & 2.0 & 2.0 & 2.0 & 2.0 & & 2.0 \\
\hline 6PGD & 2.5 & 2.1 & 2.1 & 2.3 & 2.3 & 2.1 & 2.1 & 2.1 \\
\hline G6PD . & 3.7 & 2.9 & 2.9 & 2.9 & 2.9 & 2.9 & 2.9 & 2.9 \\
\hline Ala DH & 1.16 & 1.07 & 1.07 & & Multi $^{a}$ & $1.07 ; 1.20$ & & 1.07 \\
\hline Leu DH & .0 .99 & $1.00^{b}$ & $1.00^{b}$ & 0.99 & 0.99 & $1.00^{b}$ & $1.00^{b}$ & $1.00^{b}$ \\
\hline MDH ... & $\ldots 1.52$ & 1.52 & 1.52 & 1.52 & 1.52 & 1.49 & 1.52 & 1.52 \\
\hline Catalase & $\ldots 0.44$ & 0.44 & 0.44 & 0.44 & 0.44 & 0.44 & 0.44 & 0.44 \\
\hline Esterase ... & $\ldots 0.47$ & 0.47 & 0.47 & 0.47 & 0.47 & 0.47 & 0.47 & 0.47 \\
\hline Esterase . . . & 0.97 & & & & 0.71 & & & \\
\hline AK $\ldots \ldots \ldots$ & $\ldots 1.14$ & 1.10 & 1.10 & 1.10 & 1.10 & 1.10 & 1.10 & 1.10 \\
\hline TPI . & 3.9 & 3.5 & 3.5 & 3.5 & 3.5 & 3.5 & 3.5 & 3.5 \\
\hline PP . & .0 .99 & 0.99 & & & & 0.99 & & 0.99 \\
\hline
\end{tabular}

${ }^{a}$ This was a group of evenly spaced bands with relative migration ratios of $1.12,0.99,0.88$, and 0.69 .

${ }^{b}$ The Leu DH band in these bacteria migrated at the same rate as the Leu DH type found in $B$. cereus.

TABLE 5. B. pumilus: relative electrophoretic migration distances of enzymes

\begin{tabular}{|c|c|c|c|c|c|c|c|c|c|c|c|c|c|c|c|c|}
\hline \multirow[b]{2}{*}{ Enzyme } & \multirow[b]{2}{*}{ 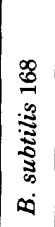 } & \multicolumn{15}{|c|}{ B. pumilis } \\
\hline & & 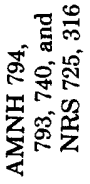 & 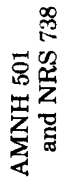 & 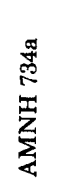 & 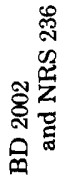 & 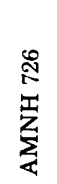 & 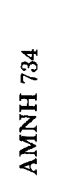 & $\begin{array}{l}\text { 岕 } \\
\text { 点 } \\
\text { مी }\end{array}$ & 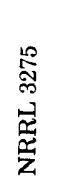 & 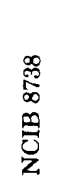 & 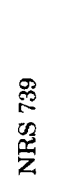 & 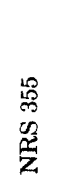 & 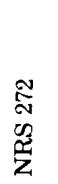 & 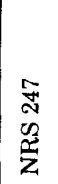 & $\begin{array}{l}\underset{J}{J} \\
0 \\
\tilde{Z} \\
\mathbf{Z}\end{array}$ & $\frac{\vec{J}}{\stackrel{J}{J}}$ \\
\hline SD ... & 2.2 & 2.2 & 2.2 & 2.2 & $2.0^{a}$ & 2.0 & 2.2 & 2.0 & 2.2 & 2.2 & 2.2 & 2.2 & 2.2 & 2.2 & 2.2 & 2.2 \\
\hline $\begin{array}{l}\text { 6PGD } \\
6 \mathrm{PGD}\end{array}$ & 2.5 & 2.5 & $\begin{array}{l}2.5 \\
2.7\end{array}$ & 2.5 & & 2.5 & 2.5 & 2.5 & & $\begin{array}{l}2.4 \\
2.7\end{array}$ & 2.5 & 1.93 & 1.93 & 1.75 & 2.2 & 2.5 \\
\hline G6PD . . & 3.7 & 3.7 & 3.7 & 3.7 & 3.7 & 3.7 & 3.7 & 3.7 & 3.7 & 3.9 & 3.7 & $3.2^{b}$ & 3.2 & 3.2 & 3.2 & 3.7 \\
\hline Ala DH & 1.16 & $1.20^{c}$ & 1.20 & & 1.20 & 1.20 & 1.20 & 1.20 & 1.20 & 1.20 & 1.20 & 1.17 & 1.17 & 1.17 & 1.17 & 1.05 \\
\hline Leu DH & 0.99 & $0.93^{d}$ & 0.93 & 0.93 & 0.93 & 0.93 & 0.93 & 0.93 & 0.93 & 0.93 & 0.93 & 0.93 & 0.93 & 0.93 & 0.93 & 0.93 \\
\hline $\mathrm{MDH}$ & 1.52 & 1.58 & 1.58 & 1.58 & 1.58 & 1.58 & 1.52 & 1.58 & 1.52 & 1.58 & 1.58 & 1.58 & 1.48 & 1.58 & 1.58 & $1.42^{e}$ \\
\hline Catalase & 0.44 & 0.44 & 0.44 & 0.44 & 0.44 & 0.44 & 0.44 & 0.44 & 0.44 & 0.44 & 0.44 & 0.44 & 0.44 & 0.44 & 0.44 & 0.35 \\
\hline Esterase & 0.47 & 0.39 & 0.39 & 0.02 & 0.44 & 0.44 & 0.44 & 0.44 & 0.44 & 0.41 & 0.39 & 0.40 & 0.40 & 0.40 & 0.42 & 0.43 \\
\hline Esterase & 0.97 & & & & & & & & & & & & & & & \\
\hline $\mathrm{AK} \ldots$ & 1.14 & 0.99 & 0.99 & 0.99 & 0.99 & 0.99 & 0.99 & 0.99 & 0.99 & 0.99 & 0.99 & 0.84 & 0.84 & 0.98 & 0.93 & 1.05 \\
\hline TPI & 3.9 & 3.7 & 3.7 & 3.7 & 3.7 & 3.7 & 3.7 & 3.7 & 3.7 & 3.7 & 3.7 & 4.2 & 4.2 & $4.2^{\mu}$ & 4.2 & 4.0 \\
\hline PP. & 0.99 & $0.88^{h}$ & 0.88 & 0.88 & 0.88 & & & 0.88 & & 0.88 & & $1.09^{i}$ & 1.09 & & 0.96 & 0.96 \\
\hline
\end{tabular}

a This was identical to the SD band found in $B$. pulvifaciens.

"This was identical to the G6PD type in B. subtilis subsp. niger.

'The Ala DH band in B. pumilus was identical to (matches) that in $B$. cereus under the electrophoresis conditions used.

$d$ This band was identical to the Leu DH band in $B$. amyloliquefaciens.

'This band was identical to the MDH band found in $B$. cereus.

1 This was identical to the AK band in $B$. cereus.

${ }^{*}$ This TPI band migrated slightly faster than the band in $B$. pumilus NRS 272 although the difference was not great enough to produce a difference in the average relative migration ratio.

$h$ This was identical to the PP band in $B$. firmus.

'This matched the PP band in $B$. sphaericus.

of $B$. coagulans was quite different (Table 9).

The electrophoretic data for enzymes of $B$. pumilus are summarized in Table 5. The type culture, NRS 272 , fell into a group, biotype I, containing three other strains. Another group of 16 strains differed from the type strain in 8 enzymes out of 11 and thus formed biotype II. However, one of these enzymes, $\mathrm{MDH}$, appeared to be a unique enzyme in the type strain, and the other three strains of biotype I differed from a typical strain of biotype II in only 7 enzymes out of 11. Many strains of biotype II also differed from $B$. subtilis in 7 enzymes out of 11 , and they also differed from any other Bacillus species described in this paper. The last $B$. pumilus strain, M-24-1, differed from the other 20 in at least 7 enzymes out of 11 which were compared, and it was distinct in DNA base composition with a density of $1.706 \mathrm{~g} / \mathrm{cm}^{3}$. The other 20 strains of Table 5 were identical in DNA density 
TABLE 6. Comparative electrophoretic migrations of enzymes in B. amyloliquefaciens and B. laterosporus

\begin{tabular}{|c|c|c|c|c|c|c|c|c|c|c|c|}
\hline Enzyme & 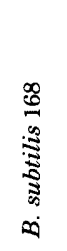 & 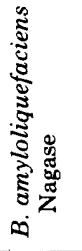 & 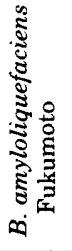 & 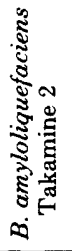 & 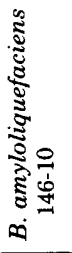 & 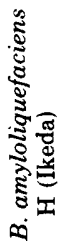 & 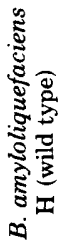 & 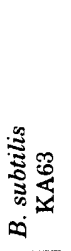 & 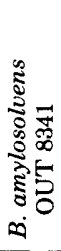 & 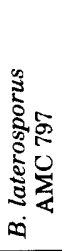 & 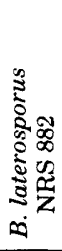 \\
\hline SD & 2.2 & 2.2 & 2.2 & 2.2 & 2.2 & 2.2 & 2.2 & 2.2 & 2.2 & 2.1 & 2.1 \\
\hline 6PGD & 2.5 & $2.5^{a}$ & $2.5^{a}$ & $2.5^{a}$ & $2.5^{a}$ & $2.5^{a}$ & $2.5^{a}$ & $2.5^{a}$ & $2.5^{\alpha}$ & & \\
\hline G6PD & 3.7 & 3.2 & 3.2 & & & 3.2 & 3.2 & 3.2 & 3.2 & & \\
\hline G6PD & & 3.7 & 3.7 & & & & & & & & \\
\hline Ala DH & 1.16 & $0.90^{b}$ & 0.90 & 0.90 & 0.90 & 0.98 & 0.90 & 0.98 & 0.90 & 0.90 & 0.90 \\
\hline Leu DH & 0.99 & $0.93^{b}$ & 0.93 & 0.93 & 0.93 & 0.93 & 0.93 & 0.93 & 0.93 & 0.93 & 0.93 \\
\hline $\mathrm{MDH}$ & 1.52 & 1.38 & 1.38 & & $1.42^{c}$ & 1.38 & 1.38 & 1.38 & 1.38 & 1.38 & 1.38 \\
\hline Catalase & 0.44 & 0.45 & 0.45 & 0.45 & 0.45 & 0.45 & 0.45 & 0.45 & 0.45 & 0.45 & \\
\hline Esterase & 0.47 & 0.47 & 0.47 & 0.47 & 0.47 & 0.47 & 0.47 & 0.47 & 0.47 & & \\
\hline Esterase & 0.97 & 0.97 & 0.97 & 0.97 & 0.97 & 0.97 & $0.97^{d}$ & 0.97 & 0.97 & & \\
\hline AK $\ldots$ & 1.14 & $1.10^{e}$ & 1.10 & 1.10 & 1.10 & 1.10 & 1.10 & 1.10 & 1.10 & 0.67 & 0.67 \\
\hline TPI & 3.9 & $3.8^{f}$ & 3.8 & 3.8 & 3.8 & 3.8 & 3.8 & 3.8 & 3.8 & 3.3 & 3.3 \\
\hline PP & 0.99 & & & & & & & & & & \\
\hline
\end{tabular}

${ }^{a}$ The 6PGD type found in $B$. amyloliquefaciens appeared to be slightly different from that in $B$. subtilis but it could not be distinguished from the 6PGD band of $B$. megaterium.

${ }^{b}$ When two slices of gel were stained for Ala $\mathrm{DH}$ and Leu $\mathrm{DH}$, respectively, the bands from B. amyloliquefaciens appeared to be in the same position. However, if the gel buffer was changed from Tris-ethylenediaminetetraacetic acid-borate ( $\mathrm{pH} 8.0$ ) to Tris-citrate ( $\mathrm{pH} 7.0$ ), these two enzymes were clearly separated in $B$. amyloliquefaciens.

$c$ This appeared to match the MDH type in B. subtilis Marburg and W23.

${ }^{d}$ This strain had a third band of esterase activity at 0.65 .

${ }^{e}$ This AK band appeared identical to that found in the B. licheniformis group.

$f$ The TPI band of $B$. amyloliquefaciens differed from that of $B$. subtilis 168 , but it did appear to match the TPI band of B. subtilis Marburg and W23.

TABLE 7. Comparative electrophoretic migrations of enzymes in B. cereus and similar strains

\begin{tabular}{|c|c|c|c|c|c|c|c|c|c|c|c|c|c|c|c|}
\hline Enzyme & $\begin{array}{l}\infty \\
\stackrel{6}{0} \\
3 \\
\tilde{3} \\
\tilde{\Xi} \\
\infty \\
\infty\end{array}$ & 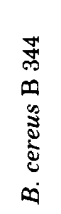 & 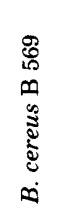 & 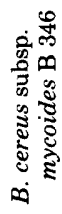 & 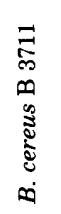 & 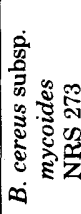 & 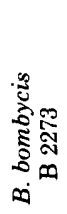 & 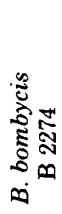 & 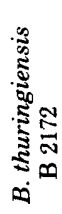 & 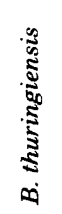 & 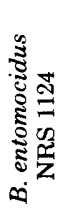 & 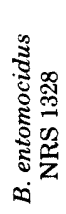 & 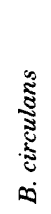 & 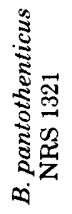 & 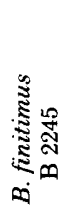 \\
\hline SD & 2.2 & 2.2 & 2.2 & 2.2 & 2.2 & 2.2 & 2.2 & 2.2 & 2.2 & 2.2 & 2.2 & 2.2 & 2.2 & 2.2 & $2.0^{a}$ \\
\hline SD & 95 & 2.3 & & & & & & 2.3 & 2.3 & & 2.3 & 2.3 & & & \\
\hline $\begin{array}{l}\text { 6PGD } \\
\text { G6PD }\end{array}$ & $\begin{array}{l}2.0 \\
3.7\end{array}$ & 4.2 & 4.2 & & & & & & & & & 4.2 & & & 4.2 \\
\hline Ala $\mathrm{DH}$ & 1.16 & 1.20 & 1.20 & 1.15 & 1.19 & 1.20 & 1.20 & 1.20 & 1.20 & 1.20 & 1.20 & 1.20 & 1.20 & 1.20 & 1.20 \\
\hline Leu DH & 0.99 & 1.00 & 1.00 & 1.00 & 1.00 & 1.00 & 1.00 & 1.00 & 1.00 & 1.00 & 1.00 & 1.00 & 1.00 & 1.00 & 1.00 \\
\hline MDH & 1.52 & $1.42^{b}$ & $1.42^{6}$ & 1.59 & $1.42^{b}$ & $1.42^{b}$ & $1.42^{b}$ & $1.42^{b}$ & $1.42^{b}$ & $1.42^{b}$ & $1.42^{b}$ & $1.42^{6}$ & 1.35 & $1.42^{b}$ & $1.42^{b}$ \\
\hline Catalase & 0.44 & 0.44 & 0.44 & 0.37 & 0.44 & 0.44 & & 0.44 & 0.44 & 0.44 & 0.44 & 0.44 & 0.44 & 0.44 & $0.45^{\prime}$ \\
\hline Esterase & 0.47 & & 0.80 & & & & 0.84 & 0.80 & 0.81 & 0.81 & & & 0.81 & 0.81 & \\
\hline Esterase & 0.97 & & & & & & & & & & & & & & \\
\hline & 1.14 & 0.99 & 0.99 & 0.99 & 0.99 & 1.08 & 0.99 & 0.92 & 0.99 & 0.99 & 0.93 & 0.99 & 0.99 & 0.99 & \\
\hline TPI & 3.9 & 4.0 & 4.0 & 3.7 & 4.0 & 4.0 & 4.0 & 4.0 & 4.0 & 4.0 & 4.0 & 4.0 & 4.0 & 4.0 & \\
\hline PP & 0.99 & 0.99 & 0.99 & & & & & & & & & & & & \\
\hline
\end{tabular}

${ }^{a}$ This was identical to the SD isozyme of $B$. pulvifaciens.

${ }^{b}$ The MDH band in most $B$. cereus strains appeared identical to that in B. subtilis W23 and B. subtilis Marburg.

' This matched the catalase band of $B$. amyloliquefaciens.

within experimental error, $1.7015 \pm 0.0006 \mathrm{~g} / \mathrm{cm}$ (Table 1).

The 16 ATCC strains were all examined for certain phenotypic properties by means of stan- dard bacteriological tests. The vegetative cells were all less than $0.9 \mu \mathrm{m}$ wide, occurred singly, and were stained uniformly. With only a few partial exceptions, the spores were oval and cen- 
TABLE 8. Comparative electrophoretic migrations of enzymes in B. megaterium and B. firmus

\begin{tabular}{|c|c|c|c|c|c|c|c|c|c|}
\hline Enzyme & $\begin{array}{c}\text { B. subtilis } \\
168\end{array}$ & $\begin{array}{c}\text { B. megate- } \\
\text { rium } \\
\text { B } 1827\end{array}$ & $\begin{array}{l}\text { B. megate- } \\
\text { rium P. B. } \\
\text { Cowles C9 } \\
\text { (M1) }\end{array}$ & $\begin{array}{c}\text { Myxogeo- } \\
\text { trichium fi- } \\
\text { larioides }\end{array}$ & $\begin{array}{l}\text { B. megate- } \\
\text { rium } \\
\text { NRS } 895\end{array}$ & $\begin{array}{l}\text { B. megate- } \\
\quad \text { rium } \\
\text { NRRL } 349\end{array}$ & $\begin{array}{c}\text { B. megate- } \\
\text { rium } \\
\text { B } 3712\end{array}$ & B. firmus & $\begin{array}{l}\text { B. firmus } \\
\text { NRS } 613\end{array}$ \\
\hline SD ... & 2.2 & 2.5 & 2.5 & 2.5 & 2.5 & 2.5 & 2.5 & 2.5 & 2.5 \\
\hline 6PGD & 2.5 & $2.5^{a}$ & $2.5^{\alpha}$ & $2.5^{\alpha}$ & $2.5^{a}$ & $2.5^{a}$ & $2.5^{a}$ & 2.1 & 2.1 \\
\hline G6PD & 3.7 & 4.2 & 4.6 & 4.2 & 4.2 & 4.2 & 4.2 & 2.9 & 2.9 \\
\hline G6PD . & & & & & 4.4 & 4.4 & & & \\
\hline Ala DH & 1.16 & 1.11 & 1.11 & 1.11 & 1.11 & 1.11 & 1.11 & 1.11 & 1.11 \\
\hline Leu DH & 0.99 & 1.00 & 1.00 & 1.00 & 1.00 & 1.00 & 1.00 & 0.93 & 0.93 \\
\hline $\mathrm{MDH}$ & .1 .52 & 1.23 & 1.23 & 1.23 & 1.23 & 1.23 & 1.23 & 1.23 & 1.23 \\
\hline Catalase & $\ldots 0.44$ & 0.44 & 0.44 & 0.44 & & 0.44 & 0.44 & 0.35 & 0.35 \\
\hline Esterase & .0 .47 & 0.83 & 0.76 & 0.77 & 0.70 & 0.70 & 0.91 & & \\
\hline Esterase & 0.97 & & & 1.07 & 0.91 & 0.91 & 1.14 & & \\
\hline Esterase & & & & & 1.14 & 1.14 & & & \\
\hline AK .... & 1.14 & & & & & & & $0.99^{b}$ & $0.99^{b}$ \\
\hline TPI & .3 .9 & 5.3 & 5.3 & 5.3 & 5.3 & 5.3 & 5.3 & 2.9 & 2.9 \\
\hline PP . & 0.99 & 1.09 & 1.09 & 1.09 & 1.09 & 1.09 & 1.09 & $0.95^{c}$ & $0.95^{c}$ \\
\hline
\end{tabular}

${ }^{a}$ The 6PGD bands of $B$. subtilis and of $B$. megaterium differed when they were in adjacent positions on the same gel, but this difference was too small to appear in the averaged relative migration rates.

${ }^{b}$ This matched the AK band in most strains of $B$. cereus.

c This appeared identical to the PP band in B. pumilus AMNH 793.

TABLE 9. Comparative electrophoretic migrations of enzymes in various Bacillus strains

\begin{tabular}{|c|c|c|c|c|c|c|c|c|c|}
\hline Enzyme & $\begin{array}{c}\text { B. subtilis } \\
168\end{array}$ & $\begin{array}{l}\text { B. alvei } \\
\text { B } 385\end{array}$ & $\begin{array}{c}\text { B. alvei } \\
\text { B } 383\end{array}$ & $\begin{array}{c}\text { B. alvei } \\
\text { NRS } 685\end{array}$ & $\begin{array}{c}\text { B. alvei } \\
\text { NRS } 662\end{array}$ & $\begin{array}{l}\text { B. sphaeri- } \\
\text { cus } \\
\text { NCIB } 9370\end{array}$ & $\begin{array}{l}\text { B. psychro- } \\
\text { philus } \\
\text { W16A }\end{array}$ & $\begin{array}{l}\text { B. stearo- } \\
\text { thermophi- } \\
\text { lus NCA } 26\end{array}$ & $\begin{array}{l}\text { B. coagu- } \\
\text { lans } \\
\text { IFO } 3557\end{array}$ \\
\hline SD . . & .2 .2 & 2.3 & 1.94 & 2.3 & 1.94 & 2.5 & $2.5^{a}$ & 1.79 & 2.1 \\
\hline 6PGD & .2 .5 & 2.1 & 2.1 & 2.2 & 2.1 & & & 1.49 & 2.0 \\
\hline G6PD & . 3.7 & 2.9 & 2.1 & 2.7 & 2.9 & & & 1.94 & $1.9^{b}$ \\
\hline G6PD . & & 3.7 & & 3.4 & 3.7 & & & & \\
\hline Ala $\mathrm{DH}$ & $\ldots 1.16$ & $1.11^{c}$ & $1.11^{c}$ & 1.00 & $1.11^{c}$ & 1.16 & 1.16 & $0.73,0.93$ & 0.56 \\
\hline Leu $\mathrm{DH}$ & .0 .99 & & & & & 1.09 & 1.00 & $0.67,0.73$ & 0.89 \\
\hline MDH . & $\ldots 1.52$ & 1.75 & 1.76 & 1.86 & 1.79 & 1.54 & 1.73 & $0.51,0.86$ & 1.06 \\
\hline Catalase & 0.44 & $0.44^{d}$ & $0.44^{d}$ & $0.44^{d}$ & $0.44^{d}$ & 0.41 & 0.41 & 0.47 & 0.44 \\
\hline Esterase & 0.47 & 0.52 & 0.52 & 0.87 & 0.52 & 0.87 & & 0.29 & $0.67^{b}$ \\
\hline Esterase & 0.97 & & & & & & & 0.61 & \\
\hline AK $\ldots$ & $\ldots 1.14$ & 1.00 & 1.00 & 1.00 & 1.00 & 0.84 & 0.84 & 0.43 & 0.89 \\
\hline TPI & $\ldots 3.9$ & 2.8 & 2.8 & 2.8 & 2.8 & 2.1 & & 3.5 & 3.1 \\
\hline $\mathrm{PP}$ & 0.99 & 0.83 & & & & $1.09^{e}$ & $1.09^{e}$ & 0.76 & 0.99 \\
\hline
\end{tabular}

${ }^{a}$ This band differed from the SD band of B. megaterium.

${ }^{b}$ We were unable to compare all of the enzymes from this strain of $B$. coagulans with other isozymes that might be similar. Specifically, we no longer had enzyme extract from $B$. stearothermophilus or $B$. megaterium NRRL B 349 to compare the G6PD and esterase enzymes, respectively.

' This was identical in migration rate to the Ala $\mathrm{DH}$ band of $B$. megaterium.

$d$ This catalase isozyme appeared on some gels to be different from that in $B$. subtilis; on other gels, they could not be distinguished.

${ }^{e}$ This PP band was not distinguishable from that found in B. pumilus NRS 272 and NRS 355.

trally located. Growth was strictly aerobic, except for slight anaerobic growth by strain 355 , and occurred in nutrient agar at $\mathrm{pH}$ 6. All strains utilized citrate but not propionate, produced acid with no gas from glucose and sucrose but not from lactose, and hydrolyzed both gelatin and casein. These strains also gave positive tests for catalase and methylene blue reduction, but not for indole. Tests in which one or more of the strains differed from the rest are listed in Table 11. Strain M-24-1 differed from all the others in starch hydrolysis, lack of hippurate reduction, and in its ability to reduce nitrate. The other strains were all very similar except for the occasional lack of a particular activity in certain strains. However, none of these differences correlated with the division into biotypes I and II.

Table 6 shows seven strains of $B$. amyloliquefaciens that formed a distinctive group differing from B. subtilis W23 in 7 enzymes (gene products) out of the 11 that were available for comparison. B. subtilis KA63 fell into this group. 
TABLE 10. Comparative electrophoretic migrations of enzymes in B. macerans and B. polymyxa

\begin{tabular}{|c|c|c|c|c|c|c|c|c|c|c|c|}
\hline Enzyme & 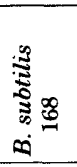 & 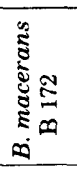 & 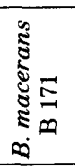 & 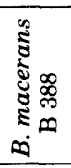 & 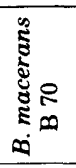 & 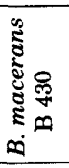 & 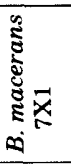 & 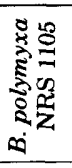 & 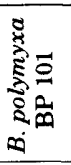 & 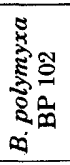 & 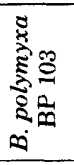 \\
\hline SD . . & 2.2 & 1.32 & 1.32 & 1.32 & 1.32 & 1.32 & 1.32 & 1.70 & 1.70 & 1.70 & 1.70 \\
\hline 6PGD & 2.5 & 1.91 & 1.91 & 1.91 & 1.91 & 1.91 & 2.0 & 1.97 & 1.97 & $2.1^{a}$ & $2.1^{a}$ \\
\hline G6PD & 3.7 & 2.4 & 2.4 & 2.4 & 2.4 & 2.4 & 2.0 & 2.7 & 2.7 & 2.8 & 2.8 \\
\hline G6PD & & $3.7^{b}$ & $3.7^{b}$ & $3.7^{b}$ & $3.7^{b}$ & $3.7^{b}$ & 3.9 & $3.7^{b}$ & 5.4 & 3.8 & 3.8 \\
\hline G6PD & & & & & & & & 5.4 & & 5.4 & 5.4 \\
\hline Ala DH & 1.16 & & & & & & & & & 0.77 & \\
\hline Leu DH & 0.99 & & & & & & & & & & \\
\hline $\mathrm{MDH}$ & .1 .52 & & & & & & & 1.52 & 1.73 & 1.73 & 1.73 \\
\hline Catalase & 0.44 & 0.44 & 0.44 & 0.44 & 0.44 & 0.44 & 0.44 & 0.44 & 0.44 & 0.44 & 0.44 \\
\hline Esterase & 0.47 & 0.51 & 0.51 & 0.51 & 0.49 & 0.49 & 0.49 & 0.24 & 0.26 & 0.11 & 0.26 \\
\hline Esterase & .0 .97 & 0.74 & 0.74 & 0.74 & 0.67 & 0.67 & 0.67 & 0.74 & 0.53 & 0.88 & 0.53 \\
\hline Esterase & & 1.02 & 1.02 & 1.02 & 0.90 & 0.90 & $\begin{array}{l}0.90 \\
1.13\end{array}$ & & 0.74 & & 0.88 \\
\hline $\mathrm{AK}$ & .1 .14 & 0.62 & 0.62 & 0.62 & 0.62 & 0.62 & 0.50 & 0.70 & 0.73 & 0.80 & 0.80 \\
\hline TPI & .3 .9 & 1.92 & 1.92 & 1.92 & 1.92 & 1.92 & 1.92 & 2.5 & 2.5 & 1.92 & 1.92 \\
\hline PP .... & 0.99 & 0.85 & 0.85 & 0.85 & 0.85 & 0.85 & 0.91 & 0.85 & & 0.66 & 0.66 \\
\hline & & & & & & & & & & 0.85 & 0.85 \\
\hline
\end{tabular}

a This 6PGD type differed from both the $B$. alvei 6PGD band and the type in $B$. firmus. It migrated more slowly than either of the above isozymes.

${ }^{b}$ This faster G6PD band, found in B. macerans, was not identical to the G6PD band of B. subtilis.

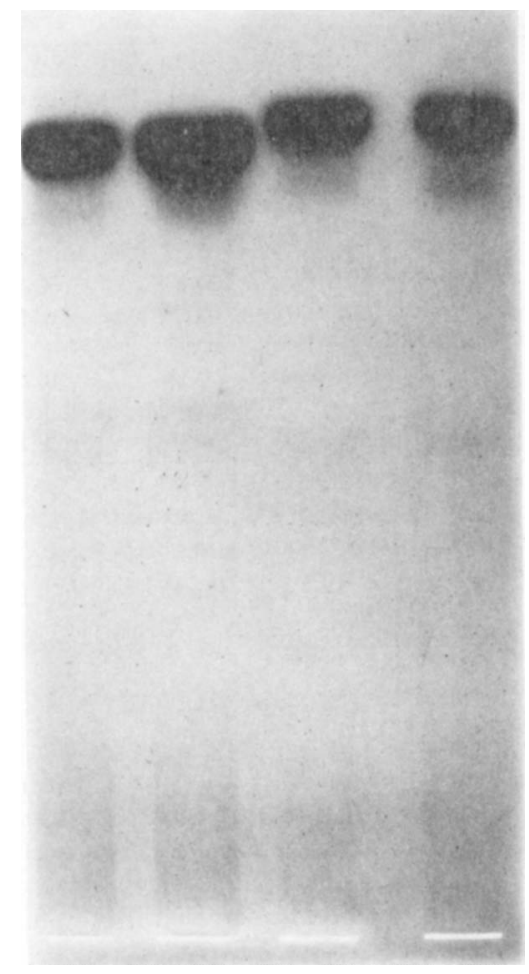

FIG. 1. Starch gel stained for 6-phosphogluconate dehydrogenase. Samples, from left to right, are: (i) $B$. subtilis 168 , (ii) $B$. subtilis $B 765$, (iii) $B$. amyloliquefaciens Fukumoto, and (iv) B. subtilis KA63.
When compared to $B$. subtilis 168 , the isozyme differences increased to 8 enzymes of 11 . The DNA density of $B$. amyloliquefaciens was also significantly higher than that of $B$. subtilis (Table 1).

Two strains of B. laterosporus were deficient in several of the enzymes usually studied, but many of the enzymes present were not distinguishable from those of $B$. amyloliquefaciens. However, differences were observed in the AK, TPI, and SD enzyme bands, and in the DNA densities.

Table 7 shows that $B$. cereus was not distinguishable from $B$. thuringiensis, $B$. bombycis, or $B$. entomocidus in terms of enzyme electrophoresis. In addition, single strains received as $B$. circulans and $B$. pantothenticus NRS 1321 also belonged to the same group. A single strain of $B$. finitimus shared four enzyme forms with this group and it had the same DNA buoyant density. The five $B$. cereus strains studied included two strains of $B$. cereus subsp. mycoides, NRS 273 and NRRL 346 . However, the two differed greatly and the latter was the most distinctive strain represented in this table. It had unique types for four enzymes out of only seven available for comparison.

Table 8 shows data for $B$. megaterium and $B$. firmus which shared three electrophoretic enzyme types of nine available for comparison. The six strains of $B$. megaterium, including one received as Myxogeotrichium filarioides (14), were all very homogeneous; differences were 
TABLE 11. Variable phenotypic properties of B. pumilus strains

\begin{tabular}{|c|c|c|c|c|c|c|c|c|}
\hline \multirow{2}{*}{$\begin{array}{c}\text { ATCC } \\
\text { strain no. }\end{array}$} & \multicolumn{2}{|c|}{ Acid from: } & \multicolumn{2}{|c|}{ Hydrolysis of: } & \multirow{2}{*}{$\begin{array}{l}\text { Dihydroxy- } \\
\text { acetone }\end{array}$} & \multirow{2}{*}{$\begin{array}{l}\text { Voges-Pros- } \\
\text { kauer }\end{array}$} & \multirow{2}{*}{$\begin{array}{c}\mathrm{KNO}_{3} \rightarrow \\
\mathrm{KNO}_{2}\end{array}$} & \multirow{2}{*}{$\begin{array}{l}\text { Growth in } \\
10 \% \mathrm{NaCl}\end{array}$} \\
\hline & Arabinose & Xylose & Starch & Hippurate & & & & \\
\hline 1 & + & $+(W)$ & - & + & - & + & - & - \\
\hline 18 & + & - & - & + & - & + & - & - \\
\hline 70 & + & - & - & + & + & + & - & - \\
\hline 71 & - & - & - & + & + & + & - & - \\
\hline 72 & + & - & - & + & - & - & - & - \\
\hline 98 & - & - & - & + & + & + & - & - \\
\hline 945 & + & - & - & + & N.T. & + & - & - \\
\hline 4510 & + & - & - & + & + & + & - & - \\
\hline 4520 & + & - & - & + & - & + & - & - \\
\hline 4522 & + & - & - & + & + & + & - & - \\
\hline 6631 & - & - & - & + & + & + & - & - \\
\hline 6632 & + & + & - & + & + & + & - & $+(W)$ \\
\hline 7061 & + & - & - & + & + & + & - & - \\
\hline 7065 & - & - & - & + & N.T. & N.T. & - & - \\
\hline 14884 & + & - & - & + & - & + & - & $+(W)$ \\
\hline 15477 & - & - & + & - & - & + & + & + \\
\hline
\end{tabular}

found only in the esterase bands of several strains and in the G6PD band of one strain.

Table 9 contains data from $B$. alvei and several other Bacillus species. The second strain of $B$. coagulans is included here and, as noted above, it was completely different from the first strain, supposedly of the same species, which is shown in Table 4. A single strain of B. psychrophilus showed some similarities to a strain of $B$. sphaericus. Of the four representatives of $B$. alvei, strain 685 was conspicuous in that it differed from the others in five enzymes out of nine compared. (In this calculation, the second band of G6PD activity was ignored.)

Finally, Table 10 shows data for $B$. macerans and $B$. polymyxa. In each case, a species-specific pattern of enzyme types was found, although the $B$. polymyxa strains were less homogeneous than those of most other Bacillus species. The five strains of $B$. macerans were separable into two groups on the basis of the esterase bands. One group included strains B 70 and ATCC 430 , and the other included strains B 171, B 172, and B 388. The four strains of $B$. polymyxa also comprised two subspecies. One included strains 101 and NRS 1105, whereas the other included strains 102 and 103.

\section{DISCUSSION}

Within the genus Bacillus, the species that have been amenable to genetic analysis via transformation and transduction ( $B$. subtilis, $B$. licheniformis, $B$. amyloliquefaciens, and $B$. pumilus) appear to constitute a distinct group of related species $(15,24,34,38,44,54)$. Indeed, Wilson and Young (54) described this complex of related taxospecies as the $B$. subtilis genospecies. In our hands, the range of base compo- sition of the DNA in the 46 specimens included in this group of strains was from 41.8 to 46.9 $\mathrm{mol} \% \mathrm{G}+\mathrm{C}$. At the upper end of this range were the eight strains of $B$. amyloliquefaciens (and unnamed strain M-24-1). This taxospecies represents the most homogeneous set encountered in this study, with but 3 of 13 proteins offering variant electrophoretic mobilities. Seki et al. (44) reported that 15 strains of $B$. amyloliquefaciens gave a mean DNA homology of $78 \%$ when measured against DNA of $B$. subtilis KA-63, a strain that they and we consider to be $B$. amylolique. faciens. B. subtilis strains showed an average DNA homology of $22 \%$ with KA63 and electromorphic similarity of $29 \%$ to the same reference strain (Table 12); reciprocal comparison of the $B$. amyloliquefaciens strains employed in each study with $B$. subtilis 168 gave $24 \%$ average DNA homology and $31 \%$ similarity of electrophoretic enzyme types. Compared on both counts (i.e., in similarity of electromorphs and in DNA sequence homology), the heterologies were not significantly different. Thus, we might conclude that, vis-à-vis this pair of related nomenspecies, both sets of measurements gave nearly identical information despite the vast difference in the basis of the data acquired by the methods.

When this comparison of DNA homologies and enzyme similarities was extended to include representatives of $B$. licheniformis, $B$. pumilus, and the more distantly related $B$. megaterium, similar reciprocal relationships of data were observed (Table 12). We note, however, that the heterology implied by the enzyme data was often somewhat less than that observed for the DNA sequence comparisons. One possible explanation for this trend is that the enzymes which we selected were coded for within a conserved core of genetic material $(15,54)$ to a greater extent 
than could be expected on a random basis. A second possibility is that the enzyme similarities were more apparent than real; at the least we are confident of the reality of the dissimilarities. A third possibility is that the enzyme data came from a more homogeneous group of strains. Nevertheless, we can define a pragmatic rule for adequately setting apart taxospecies by means of any of these quasi-genetic tools. Members of a taxospecies will have nearly identical DNA base compositions, DNA-DNA sequence homologies in excess of $50 \%$, and homologous proteins of which at least $50 \%$ will co-electrophorese. This rule is in keeping with the conclusions reached in previous studies of bacterial species $(6,7,43)$ and in studies of isozymes and their variants in eucaryotic species $(2,3,4,22,41,45$, 52 ). It is probable that it cannot easily accommodate the creation of a species as a spectrum of strains (21).

Proceeding to an evaluation of the cultures which we have studied and grouped into provisional taxa based upon the DNA base compositions and the similarity of enzyme electrophoretic mobilities, a number of conclusions can be drawn. Within the $B$. subtilis group, the taxospecies of $B$. subtilis, $B$. amyloliquefaciens, $B$. pumilus, and $B$. licheniformis were readily seen as distinct entities (Tables 13 and 14). The internal heterogeneity of $B$. subtilis was more extensive than that observed for $B$. amylolique. faciens. Among the 10 strains received as $B$. subtilis (Table 3 ), four were designated as $B$. niger or $B$. globigii. Only one of these (OUT 8111) may merit inclusion in $B$. subtilis, although it was the least typical member of the seven strains representing the species. The other three strains were nearly identical to each other and had in common with the $B$. subtilis strains only one of two esterase forms, AK and TPI, of
11 enzymes compared. They bore even less similarity to any of the other strains we examined. It would appear desirable to reopen the question of whether $B$. niger and $B$. gtobigii fall in the synonymy of $B$. subtilis or are infraspecific forms of the species $(20,21)$ rather than a distinct taxon.

With respect to $B$. licheniformis, although we initially began with but two strains bearing that name, five additional strains of the same DNA base composition yielded enzymes that migrated identically. Only two enzymes, 6PGD and Leu $\mathrm{DH}$, were distinctive of the type strain and of 9445A. It was surprising to find that the two strains of $B$. pulvifaciens (including the type strain) and single strains received as $B$. coagulans, $B$. brevis, and $B$. subtilis subsp. atterimus all fell into this single group. Should this homogeneity hold up upon examination of additional isolates, we should expect that genetic

TABLE 13. Average percentage of enzyme variants for Bacillus species

\begin{tabular}{|c|c|c|c|}
\hline Species & $\begin{array}{l}\text { No. of } \\
\text { strains }\end{array}$ & $\begin{array}{l}\text { Strain used } \\
\text { as standard }\end{array}$ & $\begin{array}{c}\text { Enzyme } \\
\text { variants } \\
(\%)\end{array}$ \\
\hline B. subtilis . & 7 & 168 & 25 \\
\hline \multicolumn{4}{|l|}{ B. amyloliquefa- } \\
\hline ciens .......... & 8 & Fukumoto & 3 \\
\hline B. licheniformis . . & 7 & B 3670 & 9 \\
\hline B. cereus ...... & 14 & B 344 & 10 \\
\hline B. megaterium & 6 & 3712 & 8 \\
\hline B. alvei ...... & 4 & B 385 & 28 \\
\hline B. macerans .... & 6 & B 172 & 21 \\
\hline \multicolumn{4}{|l|}{ B. macerans (omit } \\
\hline $7 \times 1)$ & 5 & B 172 & 11 \\
\hline B. polymyxa .... & 4 & 1105 & 44 \\
\hline \multicolumn{4}{|l|}{ B. pumilus } \\
\hline Biotype I & 4 & NRS 272 & 19 \\
\hline Biotype II & 16 & NRS 725 & 15 \\
\hline
\end{tabular}

TABLE 12. Comparison of enzyme electrophoretic mobility similarities and DNA sequence homologies

\begin{tabular}{|c|c|c|c|c|c|c|c|c|c|c|}
\hline \multirow{3}{*}{ Taxospecies } & \multicolumn{10}{|c|}{$\%$ Similarity or homology to reference cultures } \\
\hline & \multicolumn{2}{|c|}{$\begin{array}{c}\text { B. subtilis } \\
168\end{array}$} & \multicolumn{2}{|c|}{$\begin{array}{c}\text { B. amyloliquefa- } \\
\text { ciens } \\
\text { KA63 }\end{array}$} & \multicolumn{2}{|c|}{$\begin{array}{c}\text { B. licheniformis } \\
9445 \mathrm{~A}\end{array}$} & \multicolumn{2}{|c|}{$\begin{array}{l}\text { B. pumilus II } \\
\text { B } 3275\end{array}$} & \multicolumn{2}{|c|}{$\begin{array}{l}\text { B. megaterium } \\
\text { B } 3712 \mathrm{KM}\end{array}$} \\
\hline & Enzyme & DNA & Enzyme & DNA $^{a}$ & Enzyme & DNA $^{a}$ & Enzyme & $\mathrm{DNA}^{b}$ & Enzyme & $\mathrm{DNA}^{a}$ \\
\hline $\begin{array}{l}\text { B. subtilis } \\
B . \quad \text { amylolique }\end{array}$ & 74 & $84^{a}(77)^{b}$ & 26 & 22 & 38 & 11 & 37 & 16 & 9 & 5 \\
\hline faciens ...... & 31 & $24^{a}(11)^{b}$ & 91 & 78 & 23 & 13 & 14 & 5 & 11 & 4 \\
\hline B. licheniformis & 35 & $12^{a}(24)^{b}$ & 21 & 13 & 81 & 73 & 22 & 9 & 19 & 5 \\
\hline B. pumilus I ... & 21 & $-{ }^{c}(17)^{b}$ & 20 & - & 11 & - & 33 & 73 & 10 & - \\
\hline B. pumilus II . & 34 & $7^{a}(18)^{b}$ & 19 & 8 & 16 & 9 & 79 & 81 & 10 & 4 \\
\hline B. megaterium & 7 & $4^{a}-$ & 10 & 3 & 11 & 3 & 11 & $-^{c}$ & 91 & 89 \\
\hline
\end{tabular}

${ }^{a}$ Data from reference 44 .

${ }^{b}$ Data from reference 34 .

${ }^{c}$ - Not done. 
TABLE 14. Summary of similarities within various species of Bacillus

\begin{tabular}{|c|c|c|c|c|c|c|c|c|}
\hline \multirow{3}{*}{ Species } & \multirow{3}{*}{$\begin{array}{l}\text { No. of strains } \\
\text { assigned }\end{array}$} & \multirow{2}{*}{\multicolumn{2}{|c|}{$\begin{array}{l}\text { DNA composition } \\
\quad(\mathrm{mol} \% \mathrm{G}+\mathrm{C})\end{array}$}} & \multicolumn{5}{|c|}{ Enzyme mobility correspondence (\%) } \\
\hline & & & & \multirow{2}{*}{$\begin{array}{l}\text { No. in- } \\
\text { variant }^{a}\end{array}$} & \multicolumn{2}{|c|}{ Group similarity } & \multicolumn{2}{|c|}{ Similarity to type } \\
\hline & & Mean & Range & & Mean & Least & Mean & Least \\
\hline $\begin{array}{l}\text { B. subtilis } \\
\text { B. amyloliquefa- }\end{array}$ & 7 & 43.7 & $41.8-44.9$ & 5 & 69 & 45 & 74 & 36 \\
\hline ciens .......... & 8 & 46.2 & $45.9-46.9$ & 10 & 93 & 88 & 96 & 90 \\
\hline B. licheniformis & 7 & 45.9 & $45.2-46.9$ & 5 & 85 & 74 & 74 & 60 \\
\hline B. cereus ..... & 14 & 36.2 & $35.2-37.8$ & 1 & 78 & 39 & 75 & 40 \\
\hline B. megaterium & 6 & 39.2 & $38.8-40.3$ & 8 & 88 & 81 & 92 & 80 \\
\hline B. macerans ..... & 6 & 54.0 & $53.6-54.1$ & 3 & 69 & 38 & $-{ }^{b}$ & \\
\hline B. polymyxa & 4 & 46.8 & $45.9-47.4$ & 4 & 54 & 42 & 42 & 33 \\
\hline B. alvei ... & 4 & 46.8 & $45.9-47.4$ & 3 & 55 & 35 & 62 & 30 \\
\hline \multicolumn{9}{|l|}{ B. pumilis } \\
\hline Biotype I & 4 & 42.3 & $42.3-42.9$ & 5 & 70 & 59 & 72 & 55 \\
\hline Biotype II & 16 & 42.3 & $41.8-43.4$ & 6 & 85 & 70 & $-{ }^{c}$ & \\
\hline
\end{tabular}

${ }^{a}$ No other distinguishable form observed; was present in at least $50 \%$ of the extracts examined.

${ }^{b}$ No data available for type strain.

" No type strain.

transfer via transduction should be facile between motile clones of these strains.

As mentioned above, $B$. amyloliquefaciens strains exhibited a most homogeneous collection of similar enzyme types and high degree of match of DNA composition and sequence homology. Two specimens of $B$. laterosporus, including the neotype, were nearly identical to each other in all respects except the absence of any detectable catalase or peroxidase activity in the gels after electrophoresis of NRS 882 (Table 6). Despite the difference of DNA G+C contents (4 mol\% less $\mathrm{G}+\mathrm{C}$ than $B$. amyloliquefaciens), there was a surprising similarity in electrophoretic mobilities of the two amino acid dehydrogenases, $\mathrm{MDH}$, and catalase observed to those typically found in $B$. amyloliquefaciens strains. There were fewer grounds for inclusion of these strains with either $B$. alvei or $B$. cereus, where most entomogenic bacilli are found, nor was there any significant similarity of $B$. laterosporus to any other cultures which we studied. Despite this slender sampling, we accord it independent species status.

Comparison of the electrophoretic behavior of 11 enzymes separated $20 \mathrm{~B}$. pumilus strains into two distinct groups, which we designated biotypes I and II. Each of these biotypes was distinct and internally homogeneous on the basis of the electrophoresis data (Tables 13 and 14). However, phenotypic properties (Table 11), the data of Lovett and Young on DNA hybridization (34), and the susceptibility to bacteriophages (37) all failed to correlate with the division into biotypes I and II. Unfortunately, there is no test available which will clearly distinguish the two biotypes and which at the same time does not require equipment for electrophoresis. Until such a simple test is discovered, these data will be of only limited use to many bacteriologists. However, they should be considered by anyone planning studies on DNA homology or any type of genetic exchange. In particular, the fact that the type strain is genetically quite different from most strains classified as $B$. pumilus is a potential source of confusion in such studies.

The data indicate that strain M-24-1 does not belong to the species $B$. pumilus. If the DNA density and zymogram data are compared with those of other species, it will be seen that strain M-24-1 also differs from any species represented in this study.

The six strains of $B$. megaterium comprised a uniform assembly of strains that were readily diagnosed on classical taxonomic grounds, as well as by the quasi-genetic methods. We conclude that Myxogeotrichium filarioides is a synonym for B. megaterium. Although no strains were included in common with the study of DNA sequence homologies by Seki et al. (44), we have compared their homology data of the KM strain to our enzyme comparisons (Table 12). Both sets of data confirmed the essential homogeneity of the properties of the strains within this species and the slender resemblance, if any, to members of the $B$. subtilis group.

The 14 strains with $\mathrm{G}+\mathrm{C}$ contents in their DNA of $36 \mathrm{~mol} \%$ all appeared to constitute a single group identifiable as $B$. cereus. We found no grounds for distinction of the entomogenic varieties or of $B$. cereus subsp. mycoides, and this parallels the DNA homologies observed (49). The two most aberrant strains were received as B. cereus subsp. mycoides B346 (NRS 233) and $B$. finitimus NRRL B2245. These strains provided extracts devoid of many of the 
enzyme activities common to the group, hence limiting the data base for comparison and weighting very heavily the data for a few enzyme variants. A culture labeled $B$. circulans and for which no history was provided proved to be indistinguishable from $B$. cereus, but this proves nothing about the status of the nomenspecies. On the other hand, the type strain of $B$. pantothenticus fitted rather neatly with $B$. cereus. These data suggest that the poorly described and poorly circumscribed nomenspecies $(20,21)$ of $B$. pantothenticus and $B$. circulans could ultimately find synonymy with $B$. cereus.

In our study there were three more nomenspecies represented by four or more cultures. $B$. alvei was represented by four cultures, two of which represent separate lines of maintenance of the neotype strain. Two enzymes were found to migrate differently in these cultures, but we found comfort in the observation by Gordon et al. (20) that two other cultures of the strain tracing back to Lochead's 127 isolate also showed variability of cultural characters. One of our strains, showing the least similarity to the other three, had originally been designated as $B$. para-alvei, and we would question whether the examination of a larger number of strains would confirm the synonymy of these names. Six strains received as $B$. macerans had apparently identical DNA base compositions (54 mol\% $\mathrm{G}+\mathrm{C}$ ), and this value alone sets them apart from all other members of the genus Bacillus that we have studied. Five of the strains were exceedingly homogeneous in the zymographic comparison (83\% group similarity); the sixth strain (NCA 7X1) was somewhat aberrant (Tables 13 and 14), and although it had only $38 \%$ similarity to the entire group, it had 59\% similarity of electromorphs with strains B70 and B430. Sacks and Thompson (42) observed unique patterns of factors capable of stimulating the germination of spores of the 7X1 and B70 cultures, but B430 showed identical patterns to those observed for B171 and B388. We do not feel justified in recommending any alteration of the nomenclature of $B$. macerans. Four cultures received as $B$. polymyxa appeared to be a diverse group (Tables 13 and 14). The neotype strain was quite different in enzyme mobilities from the other three strains. Although $B$. polymyxa has been described as a clearly demarcated species, we would defer any comment until a larger sampling has been examined.

The remaining cultures which we examined represent nomenclatural species for which at most two strains were examined and for which no taxonomic conclusions could be drawn. What was apparent was that these cultures, from psychrophile to thermophile and varying degrees of indistinction, give a wide variety of zymograph patterns. This variety confirms our belief that this type of comparison can provide a clearer resolution of the numerous taxospecies that comprise the genus Bacillus.

A rapid test of the ability of DNA composition and electromorph similarity to delineate the species as compared to morphological and cultural characteristics alone is illustrated by computation of the same type of similarity coefficients for data presented on cultures examined in the elegant study of Gordon et al. (20). Taking the data for the first 12 cultures bearing ATCC numbers of $B$. subtilis and of $B$. cereus, which can be coded as + or - , but eliminating the characters which are genus defining (Gram reaction, catalase production), we noted that the type strain of B. subtilis is $93 \%$ similar to these B. subtilis cultures and $80 \%$ similar to the $12 B$. cereus strains. The converse comparison of the $B$. cereus type strain is $100 \%$ to $B$. cereus, but $73 \%$ to $B$. subtilis. It follows that the availability of more primitive data (e.g., DNA composition, DNA sequence homology, zymogram data, and amino acid sequences of homologous proteins) can provide a guidepost for the selection of cultural characteristics that are diagnostic and aid in less ambiguous assignment of cultures to taxospecies.

\section{ACKNOWLEDGMENTS}

This investigation was supported by Public Health Service grant GM-15597 from the National Institute of General Medical Sciences and National Science Foundation grant BMS 7406285.

We thank Beulah S. Harriell for skillful technical assistance. We also thank $W$. C. Haynes for many valuable suggestions, R. E. Gordon for advice, C. R. Shaw for support and encouragement, and the many investigators who provided cultures employed in this study.

\section{REPRINT REQUESTS}

Address reprint requests to: Dr. Manley Mandel, Dept. of Biology, The University of Texas System Cancer Center, M. D. Anderson Hospital and Tumor Institute, Houston, TX 77030 .

\section{LTTERATURE CITED}

1. Adams, J., and S. Allen. 1975. Genetic polymorphism and differentiation in Paramecium, p. 867-882. In C. L. Markert (ed.), Isozymes IV. Academic Press Inc., New York.

2. Ayala, F. J., C. A. Mourao, S. Pérez-Salas, R. Richmond, and T. Dobzhansky. 1970. Enzyme variability in the Drosophila willistoni group. I. Genetic differentation among sibling species. Proc. Natl. Acad. Sci. U.S.A. $67: 225-232$.

3. Ayala, F. J., J. R. Powell, M. L. Tracey, C. A. Mourao, and S. Perez-Salas. 1972. Enzyme variability in the Drosophila willistoni group. IV. Genic variation in natural populations of Drosophila willistoni. Genetics 70:113-139.

4. Ayala, F. J., and M. L. Tracey. 1974. Genetic differentiation within and between species of the Drosophila willistoni group. Proc. Natl. Acad. Sci. U.S.A. 71:999-1003. 
5. Ballard, R. W., N. J. Palleroni, M. Doudoroff, R. Y. Stanier, and M. Mandel. 1970. Taxonomy of the aerobic pseudomonads: Pseudomonas cepacia, P. marginata, $P$. alliicola and P. caryophylli. J. Gen. Microbiol. 60:199-214

6. Baptist, J. N., C. R. Shaw, and M. Mandel. 1969. Zone electrophoresis of enzymes in bacterial taxonomy. J. Bacteriol. 99:180-188.

7. Baptist, J. N., C. R. Shaw, and M. Mandel. 1971. Comparative zone electrophoresis of enzymes of Pseudomonas solanacearum and Pseudomonas cepacia. J. Bacteriol. 108:799-803.

8. Baptist, J. N., M. J. Tevethia, M. Mandel, and C. R. Shaw. 1974. Altered proteins with triosephosphate isomerase activity in suppressor-containing strains of Bacillus subtilis. J. Bacteriol. 119:976-985.

9. Beauchamp, C., and I. Fridovich. 1971. Superoxide dismutase: improved assays and an assay applicable to acrylamide gels. J. Anal. Biochem. 44:276-287.

10. Bernstein, S. C., L. H. Throckmorton, and J. L. Hubby. 1973. Still more genetic variability in natural populations. Proc. Natl. Acad. Sci. U.S.A. 70:3928-3931

11. Bonde, G. J. 1973. The genus Bacillus, Series no. 2. ISS Research Councils, Copenhagen.

12. Boyer, S. H. 1972. Extraordinary incidence of electrophoretically silent genetic polymorphisms. Nature (London) 239:453-454.

13. Brenner, D. J., G. R. Fanning, K. E. Johnson, R. V. Citarella, and S. Falkow. 1969. Polynucleotide sequence relationships among members of Enterobacteriaceae. J. Bacteriol. 98:637-650.

14. Castellani, A. 1965. Further observations on Myxomicrobium multiplex and a preliminary report on another peculiar pleomorphic slime organism isolated from human lesions. Mycopathol. Mycol. Appl. 26:359-372.

15. Chilton, M. D., and B. J. McCarthy. 1969. Genetic and base sequence homologies in bacilli. Genetics 62:697-710.

16. De Barjac, H., and A. Bonnefoi. 1972. Essai de classification biochimique de 64 bacillus des groupes II et III representant especes differentes. Ann. Inst. Pasteur (Paris) 122:463-473.

17. De Barjac, H., and M. A. Bonnefoi. 1967. Classification des souches de Bacillus thuringiensis. C. R. Acad. Sci. (Paris) 264:1811-1813.

18. Fox, G. E., K. R. Pechman, and C. L. Woese. 1977. Comparative cataloging of $16 \mathrm{~S}$ ribosomal ribonucleic acid. Int. J. Syst. Bacteriol. 27:44-57.

19. Gibson, T., and R. E. Gordon. 1974. Bacillus Cohn 1872 , p. 529-550. In R. E. Buchanan and N. E. Gibbons (ed.) Bergey's manual of determinative bacteriology, 8th ed. The Williams \& Wilkins Co., Baltimore.

20. Gordon, R. E., W. C. Haynes, and C. H.-N. Pang. 1973 The genus Bacillus. Agriculture Handbook No. 427. U.S. Department of Agriculture, Washington, D.C.

21. Gordon, R. E., J. L. Hyde, and J. A. Moore, Jr. 1977. Bacillus firmus-Bacillus lentus: a series or one species? Int. J. Syst. Bacteriol. 27:256-262

22. Grassle, J. P., and J. F. Grassle. 1976. Sibling species in the marine pollution indicator Capitella (Polychaeta). Science 192:567-569.

23. Hemphill, H. E., and H. R. Whiteley. 1975. Bacteriophages of Bacillus subtilis. Bacteriol. Rev. 39:257-315.

24. Ikeda, Y., H. Saito, K. I. Miura, J. Takagi, and H. Aoki. 1965. DNA base composition, susceptibility to bacteriophages and interspecific transformation as criteria for classification in the genus Bacillus. J. Gen. Appl. Microbiol. 11:181-190.

25. Jensen, R. A., D. S. Nasser, and E. W. Nester. 1967. Comparative control of a branch point enzyme in microorganisms. J. Bacteriol. 94:1582-1593.

26. Johnson, W. E., H. L. Carson, K. Y. Kaneshiro, W. W. M. Steiner, and M. M. Cooper. 1975. Genetic variation in Hawaiian Drosophila. II. Allozymic differentiation in the $D$. plantibia subgroup, p. 563-584. In C. L. Markert (ed.), Isozymes IV. Academic Press Inc., New York.

27. King, J. L., and T. H. Jukes. 1969. Non-Darwinian evolution. Science 164:788-798.

28. King, J. L., and T. Ohta. 1975. Polyallelic mutational equilibria. Genetics 79:681-691.

29. Knight, B. C. J. G., and H. Proom. 1950. A comparative survey of the nutrition and physiology of mesophilic species in the genus Bacillus. J. Gen. Microbiol. 4:508-538.

30. Lakovaara, S., A. Saura, and C. T. Falk. 1972. Genetic distance and evolutionary relationships in the Drosoph ila obscura group. Evolution 26:177-184.

31. Leffert, H. L., J. N. Baptist, and L. I. Gidez. 1970 Meningitis and bacteremia after ventriculoarterial shunt-revision: isolation of a lecithinase-producing $\mathrm{Ba}$ cillus cereus. J. Infect. Dis. 122:547-552.

32. Lemille, F., H. De Barjac, and A. Bonnefoi. 1969. Essai sur la classification biochimique de 97 Bacillus du groupe I appartenant a 9 especes differentes. Ann. Inst. Pasteur (Paris) 116:808-819.

33. Lepesant-Kejzlarova, J., J. A. Lepesant, J. Walle, A. Billault, and R. Dedonder. 1975. Revision of the linkage map on Bacillus subtilis 168: indications for circularity of the chromosome. J. Bacteriol 121:823-834.

34. Lovett, P. S., and F. E. Young. 1969. Identification of Bacillus subtilis NRRL B-3275 as a strain of Bacillus pumilus. J. Bacteriol. 100:658-661.

35. Lovett, P. S., and F. E. Young. 1970. Genetic analysis in Bacillus pumilus by PBS1-mediated transduction. J. Bacteriol. 101:603-608.

36. Lovett, P. S., and F. E. Young. 1971. Linkage groups in Bacillus pumilus determined by bacteriophage PBS1mediated transduction. J. Bacteriol. 106:697-699.

37. Lovett, P. S. 1972. PBPI: a flagella specific bacteriophage mediating transduction in Bacillus pumilus. Virology 47:743-752.

38. Marmur, J., E. Seaman, and J. Levine. 1963. Interspecific transformation in Bacillus. J. Bacteriol. 85:461-467.

39. Milkman, R. 1973. Electrophoretic variation in Esche richia coli from natural sources. Science 182: $1024-1026$.

40. Norris, J. R. 1964. The classification of Bacillus thuringiensis. J. Appl. Bacteriol. 27:439-447.

41. Richmond, R. C. 1972 . Genetic similarities and evolutionary relationships among the semispecies of Drosophila paulistorum. Evolution 26:536-544.

42. Sacks, L. E., and P. A. Thompson. 1971. Germination requirements of Bacillus macerans spores. J. Bacteriol. 105: 739-746.

43. Seidler, R. J., M. Mandel, and J. N. Baptist. 1972. Molecular heterogeneity of the bdellovibrios: evidence for two new species. J. Bacteriol. 109:209-217.

44. Seki, T., T. Oshima, and Y. Oshima. 1975. Taxonomic study of Bacillus by deoxyribonucleic acid-deoxyribonucleic acid hybridization and interspecific transformation. Int. J. Syst. Bacteriol. 25:258-270.

45. Shaw, C. R. 1971. The extent of genetic divergence in speciation. Cons. Int. Explor. Mer. Extr. Rapp. Proc. Verb. 161: 143-146.

46. Shaw, C. R., and R. Prasad. 1970. Starch gel electrophoresis of enzymes-a compilation of recipes. Biochem. Genet. 4:297-320.

47. Siciliano, M., and C. R. Shaw. 1976. Separation and visualization of enzymes on gels, p. 185-209. In I. Smith (ed.), Chromatographic and electrophoretic techniques, vol. 2, 4th ed. Yearbook Medical Publishers, Chicago.

48. Smith, N. R., R. E. Gordon, and F. E. Clark. 1946 Aerobic mesophilic sporeforming bacteria. U.S. Depart- 
ment of Agriculture Miscellaneous Publication No. 559 U.S. Department of Agriculture, Washington, D.C.

49. Somerville, H. J., and M. L. Jones. 1972. DNA competition studies within the Bacillus cereus group of bacilli. J. Gen. Microbiol. 73:257-265.

50. Stout, D. L., and C. R. Shaw. 1974. Genetic distance among certain species of Mucor. Mycologia 66:969-977.

51. Stout, D. L., and C. R. Shaw. 1973. Comparative enzyme patterns in Thamnidium elegans and $T$. anomalum. Mycologia 65:803-808.

52. Webster, T. P., R. K. Selander, and S. Y. Yang. 1972 Genetic variability and similarity in the Anolis lizards of Bimini. Evolution 26:523-535.
53. Welker, N. E., and L. L. Campbell. 1967. Unrelatedness of Bacillus amyloliquefaciens and Bacillus subtilis. J. Bacteriol. 94:1124-1130.

54. Wilson, G. A., and F. E. Young. 1972. Intergenetic transformation of the Bacillus subtilis genospecies. J. Bacteriol. 111:705-716.

55. Wolf, J., and A. N. Barker. 1968. The genus Bacillus: aids to the identification of its species, p. 93-109. In B. M. Gibbs and D. A. Shapton (ed.), Identification methods for microbiology. Academic Press Inc., New York.

56. Yost, F. J., and I. Fridovich. 1973. An iron-containing superoxide dismutase from Escherichia coli. J. Biol. Chem. 248:4905-4908. 